\title{
SÍNDROME DA ALIENAÇÃO PARENTAL, UMA INÍQUA FALÁCIA ${ }^{1}$
}

\author{
Cláudia Galiberne Ferreira ${ }^{2}$ \\ Romano José Enzweiler ${ }^{3}$
}

Resumo: As locuções "alienação parental” (AP) e "síndrome da alienação parental" (SAP) passaram, há pouco, a fazer parte do vocabulário jurídico nacional, sendo utilizadas pelos Tribunais de todo o país só muito recentemente, em casos envolvendo divórcios conturbados. A matéria se viu positivada no Brasil há exatos quatro anos, a partir da edição da Lei n. 12.318, de agosto de 2010, tendo aqui recebido aplausos quase unânimes, o que parece ocorrer de forma burlescamente acrítica, até porque nenhum outro país editou lei acerca do tema e os Tribunais e sociedades de psiquiatria dos mais tradicionais países ocidentais a rechaçam consistentemente. A já vasta literatura nacional sobre o tema, em sua maioria absoluta, mostra-se francamente favorável à aplicação da lei e à posição

1 Este texto é dedicado ao Juiz de Direito Edson Luiz de Oliveira, titular da Vara da Família da Comarca de São Bento do Sul/SC, ser humano de qualidades raras e que tanto enobrece a Magistratura, incentivador presente e, de muitas formas, corresponsável pelo resultado da nossa pesquisa. A versão final deste ensaio contou com a generosa leitura e argutas observações do Juiz de Direito Hélio do Valle Pereira, titular da Vara dos Feitos da Fazenda da Comarca de Florianópolis/SC e hoje no TRE/SC, seguramente uma das mentes mais brilhantes e espetaculares que há no Judiciário brasileiro. Revisão gramatical realizada pela competentíssima Profa. MSc. Maria Tereza de Queiroz Piacentini.

2 Advogada em Santa Catarina, pós-graduada em Direito Processual Civil pela CESUSC/Florianópolis-SC. Coautora do livro "Curso de Direito Médico", São Paulo: Conceito Editorial, 2011. Coautora do texto "O novo CPC e a oportunidade desperdiçada", publicado pela Revista da Escola Superior da Magistratura do Estado de Santa Catarina, v. 20, n. 26, 2013, p. 29-44. E-mail: clagferreira@gmail.com

3 Juiz de Direito em Santa Catarina. Mestre em Relações Econômicas e Sociais Internacionais, Uminho, Braga, Portugal. Mestre em Gestão de Políticas Públicas, Univali, Itajaí, Brasil. Doutorando em Direito, Universidade do Porto, Portugal. E-mail: romanoenzweiler@tjsc.jus.br 
do idealizador do termo SAP, o norte-americano Richard Gardner. A nova lei, diz silenciosa minoria, por ter sido aprovada por um Parlamento marcadamente masculino (os homens configuram 91,23\% da Câmara dos Deputados e $85,2 \%$ o Senado da República, o que é objeto de perplexidade internacional, conforme revela o Comitê (edaw, da ONU ${ }^{4}$ ) - em que boa parte de seus membros se vê ali espelhada e "na pele" do devedor de alimentos aos filhos e à ex-mulher -, exprime forte preconceito de gênero, mostra-se antinômica e se encontra repleta de conceitos vagos e sanções (a serem aplicadas logicamente, na imensa maioria dos casos, às mulheres) no mínimo temerárias, por terem estas como destinatários finais, perversamente, não a ex-mulher, mas justamente os filhos que todos dizem querer preservar.No Brasil, ao contrário do que há muito se dá em Europa e nos Estados Unidos, inexiste discussão acadêmica mais densa e responsável acerca da AP e da SAP, fragilidade essa que se vê, então, refletida nas decisões judiciais.

Palavras-chave: Alienação parental. Síndrome. Preconceito de gênero. Adultismo. Vulnerabilidade materna. Backlash.

\section{INTRODUÇÃO}

A proposta central deste texto é o enfrentamento sincero e em bases científicas do "neomodismo" jurídico denominado "alienação parental" (AP) e daquilo que alguns denominam de "síndrome da alienação parental" (SAP).

Verificar-se-á, primeiro, a origem do termo e os supostos fundamentos que sustentam a "teoria" para, em seguida, apresentar as posições contrárias e suas razões. Ao depois, passa-se à análise de fenômenos como preconceito de gênero, adultismo,

4 http://memoria.ebc.com.br/agenciabrasil/noticia/2012-02-17/pequena-proporcaode-mulheres-no-congresso-nacional-brasileiro-e-motivo-de-preocupacao-paraonu. Consulta em 4/9/2014. 
estímulo à vulnerabilidade materna e backlash, incursionando sobre o sensível tema respeitante à guarda dos filhos. Aborda-se, também, a questão ligada às falsas acusações de alienação parental e suas consequências. Por fim, e agora buscando ligar teoria à prática, investiga-se o tratamento legal e jurisprudencial emprestado à AP e à SAP no Brasil, não se furtando os autores de apresentar, no último tópico, suas conclusões pessoais.

\section{ALIENAÇÃO PARENTAL (AP). A POPULARIZAÇÃO DO CONCEITO POR RICHARD GARDNER. A "SÍNDROME" DA ALIENAÇÃO PARENTAL (SAP)}

O fenômeno descrito como alienação parental (AP) ocorre quando, na definição de Stahl, "uma criança imotivadamente rejeita um dos pais devido à influência do outro genitor, o que se verifica com a contribuição da própria criança"

Nominado por alguns como "Medea syndrome", "divorce related malicious mother syndrome", "parental alignments", "programmed and brainwashed children", "overburdened children ${ }^{10 " 11,}$ "parental alienation disorder"12 (PAD)", ou "parental alienation relational problem ${ }^{13}$ (PARP)", o termo ganhou notoriedade no

5 No original: "as a child unreasonable rejection of one parent due to the influence of the other parent combined with the child's own contributions". STAHL, Philip M. Understanding and Evaluating Alienation in High-Conflict Custody Cases, p.1. Tradução livre e adaptada.

6 "Medea", Medeia em português, conhecido personagem mitológico, significando, com isso, a existência de sentimentos contraditórios e profundamente cruéis. BULFINCH, Thomas. O livro de ouro da mitologia: histórias de deuses e heróis. Tradução de David Jardim Júnior. 8 ed. rev. e ilustrada. Rio de Janeiro: Ediouro, 1999, p.164.

7 Curiosamente denominado de "divórcio relacionado à síndrome da mãe maliciosa". Tradução livre do original.

8 "Alinhamento dos pais". Tradução livre do original.

9 "Crianças programadas e submetidas a lavagem cerebral". Tradução livre do original.

10 "Crianças com enorme fardo". Tradução livre do original.

11 RAND, Deirdre C. Parental Alienation Critics and the Politics of Science, p.48.

12 "Desordem da alienação parental". Tradução livre do original.

13 "Alienação parental como problema relacional”. Tradução livre do original. 
ano de 1985, com a publicação de trabalho seminal de Richard Gardner, médico e perito norte-americano ${ }^{14}$.

Gardner é tido como responsável por cunhar o termo inglês PAS ${ }^{15}$, entre nós conhecido como SAP - Síndrome de Alienação Parental -, "expressão que se refere à "programação" ou à "lavagem cerebral" promovida por um dos pais da criança a fim de denegrir e vilipendiar o outro genitor, acrescentando elaborações "construidas" pelo próprio infante, e assim justificar sua resistência a manter uma relação com tal genitor, que é definido como alienado"16.

De acordo com Gardner, oito pontos compõem tal "síndrome":

$1^{\circ}$. uma campanha de difamação contra o genitor-alvo;

$2^{\circ}$. racionalizações frívolas para a crítica da criança em relação ao genitor-alvo;

$3^{\circ}$. ausência de ambivalência (valores iguais);

4\%. o fenômeno do pensador independente, isto é, afirmações contundentes de que a decisão de rejeitar o genitor é só dela (a criança);

14 Gardner trabalhou grande parte de sua vida como perito judicial em litígios envolvendo casos de pedofilia, isto é, abuso sexual em que eram acusados os pais (homens), professores e membros de congregações religiosas (padres, pastores, bispos). Em seus laudos e textos, ele recomendava ao Tribunal a retirada das crianças da casa dos "alienantes" para colocá-los sob a guarda dos pais apontados como autores do abuso sexual. Sua teoria provocou compreensível e veemente oposição entre os profissionais de saúde mental do mundo inteiro. Assim, de fato, a teoria de Gardner acerca da alienação parental teve início a partir de demandas judiciais envolvendo abuso sexual infantil (pedofilia), o que era por ele considerado produto de uma espécie de histeria nacional. Gardner suicidou-se no ano de 2003.

15 PAS - Parental alienation syndrome. O modelo linear de Gardner, no qual existe uma única causa (alienante) e um efeito óbvio (alienação), sugere que quando há uma criança que recusa a visitação e um(a) genitor(a) que apoia tal decisão, estaremos diante de um caso de alienação parental. STHAL, Philip M., Understanding and Evaluating Alienation in High-Conflict Custody Cases, p. 1.

16 No original: "Según el autor que lo inventó y le dio el estatus de síndrome "médico" (Gardner, 1985), se refiere a la "programación" o "lavado de cérebro" hecho por un progenitor sobre el niño, con el fin de "denigrar" y "vilipendiar" al otro progenitor (añadiéndose elaboraciones "construidas" por el proprio menor ) y así justificar la resistencia del niño/a a mantener una relación con dicho progenitor, al cual se define como alienado". Revista de la Asociación Española de Neuropsiquiatria, vol. 30, núm. 107, septiembre 2001, p. 535-49, Asociación Española de Neuropsiquiatria, España. Tradução livre e adaptada. 
5०. apoio reflexivo do genitor alienador contra o genitor-alvo;

60. ausência de culpa do genitor-alvo acerca dos alegados maus-tratos ou exploração (sexual) supostamente sofridos pela criança;

7\%. cenários, frases e situações emprestadas do genitor alienante e;

8. espraiamento da animosidade da criança em direção à família estendida do genitor-alvo ${ }^{17}$.

\section{DIVERGÊNCIAS APONTADAS PELA CIÊNCIA INTERNACIONAL: EXISTE UMA SÍNDROME ${ }^{18} ?$ A AUSÊNCIA DE CIENTIFICIDADE DA TEORIA SAP}

Ao contrário da aparente unanimidade de que desfrutam a AP e a SAP no meio jurídico brasileiro (academia e tribunais), sua real existência como síndrome, categorização, conceito e possíveis tratamentos têm sido objeto de intensa, séria e acalorada discussão em países de larga tradição científica, como Estados Unidos, Inglaterra, Espanha e Portugal, a.e.

Conforme Rand ${ }^{19}$, há dois principais grupos a que se filiam os críticos da SAP (e do próprio conceito de alienação parental): (1) o primeiro grupo é composto principalmente por profissionais da área da saúde mental, pesquisadores de divórcio e outras pessoas que trabalham com direito de família, para os quais as questões envolvendo guarda e visitação [dos filhos] são difíceis. (...) De acordo com esses críticos, as duas questões mais controvertidas no debate acerca da SAP são a ênfase de Gardner sobre o papel causal do genitor alienante e as intervenções aparentemente radicais daí decorrentes, como a mudança da guarda em favor do genitor dito alienado (supostamente "odiado" pela

17 BERNET, William; BAKER, Amy J. L. Parental Alienation, DSM-5, and ICD-11: Response to Critics, p. 2.

18 Síndrome aqui tomada como o "conjunto de sintomas que se apresentam numa doença e que a caracterizam". In Dicionário eletrônico Michaelis, in http://michaelis.uol.com.br/.

19 RAND, Deidre C., Parental Alienation Critics and the Politics of Science, p. 48. 
criança). (2) O segundo grupo se identifica como defensores das mulheres e crianças abusadas. (...) Para estes críticos, Gardner equipara, equivocadamente, as questões envolvendo falsas alegações de abuso sexual com a definição de SAP. Conforme essa corrente, têm os Tribunais aceito, acriticamente, a ligação promovida por Gardner entre SAP e alegações de abuso sexual. $\mathrm{Na}$ leitura dos defensores dessa linha, os Tribunais, ao valer-se da doutrina Gardner, acabam por absolver o agressor do crime de abuso sexual praticado contra a criança e penalizar a mãe protetora, dando a guarda, justamente, ao transgressor, colocando assim a criança em perigo ${ }^{20}$.

Apresentam alguns autores frontal divergência à "teoria" de Gardner, desnudando suas deficiências. Assim, e.g., apresenta Bruch cinco pontos de inconsistência da SAP. Primeiro, sublinha ele, confunde Gardner as reações da criança relativamente ao divórcio (e à alta conflituosidade que envolve os pais) com psicose. Ao fazê-lo, desconhece a raiva dos pais e das crianças, comportamento esse totalmente previsível após a separação/divórcio. A duas, decorrência desse erro inicial de perspectiva, exagera Gardner as hipóteses em que ocorrem falsas alega-

20 No original: "The first group is comprised primarily of mental health professionals, divorce researchers, and others who work in the family law arena, where contested custody and visitation matters are heard. Critics in this group include contributors such as Wallerstein, Lewis, and Blakeslee (2000), Johnston, Kelly, and the other contributors to the special issue of Family Court Review (Schepard et al. (Eds.), 2001) and Emery, Otto and O'Donohue (2005). I refer to this group collectively as the Johnston/Kelly critics. According to these critics, the two most contentious issues in the PAS debate are Gardner's emphasis on the causal role of the alienating parent, and the seemingly radical interventions which flow from that, such as changing custody to the hated parent. PAS critics in the second group identify themselves as advocates for abused women and children. Critics in this group include professionals such as Bruch (2001), Faller (1998), Myers (1997), and Walker, Brantley, and Rigsbee (2004), as well as grass roots activities such as Isman (1996) and California NOW (Heim, Grieco, Di Paola \& Allen, 2002). I refer to this group as the feminist and child advocates. Critics in this group object to Gardner's views on child abuse and frequently equate false allegations of sex of sex abuse with his definition of PAS, which is a misunderstanding. According to these critics, courts have uncritically accepted Gardner's views on PAS and allegations of sex abuse. In their view, courts are quick to dismiss allegations of sex abuse by the father and to penalize protective mothers by giving the abusive father custody, thus putting the child in danger". RAND, Deidre C., Parental Alienation Critics and the Politics of Science, p. 49. Tradução livre e adaptada. 
ções ou em que se unem crianças e genitores alienantes contra o genitor alienado para destruir o relacionamento pai-filho. Para Gardner, no contexto do divórcio as alegações de abuso sexual geralmente mostram-se falsas, o que se dá sem qualquer fundamento científico e, ao contrário, vem-se demonstrando que tais acusações, em geral, possuem pertinência. Em terceiro lugar, ao retirar completamente a atenção sobre o suposto abuso sexual praticado pelo agressor, promove a SAP nova exposição da criança, pois que acaba levando a presumir que o genitor protetor está mentindo com vistas a sabotar os sentimentos da criança em relação ao agressor (alienado). A quatro, acredita Gardner que nos casos mais graves a relação de uma criança com o genitor alienado/rejeitado será irreparavelmente danificada, provavelmente para sempre, a menos que medidas imediatas, drásticas (transferência de guarda, isolamento do genitor querido e desprogramação/lavagem cerebral reversa) sejam tomadas. Aqui, também, fontes fidedignas revelam que sua teoria é no mínimo exagerada, pois os laços, mesmo em famílias com histórico de violência, seguem mantidos e tendem a se resolver quando as crianças amadurecem. A cinco e finalmente, as soluções extremas propostas por Gardner mostraram-se inadequadas por colocar em risco as crianças. Reportagem investigativa comprovou, por exemplo, a ocorrência de inúmeros casos em que os Tribunais decidiram por transferir a guarda da criança para abusadores conhecidos ou prováveis, negando aos genitores protetores qualquer contato com as crianças ${ }^{21}$.

21 No original: "First, Gardner confounds a child's developmentally related reaction to divorce and high parental conflict (including violence) with psychosis. In doing so, he fails to recognise parent's and children's angry, often inappropriate and totally predictable behaviour following separation. Second, possibly as a consequence of these errors and his tail-of-the-elephant view, Gardner vastly overstates the frequency of cases in which children and custodial parents manufacture false allegations or collude to destroy the parent-child relationship. Taken together, these assertions have the practical effect of impugning all abuse allegations, allegations which Gardner asserts are usually false in the divorce context. Here, too, Gardner, cites no evidence in support of his personal view, ant the relevant literature reports the contrary-that such allegations are usually well founded. Third, in this fashion, PAS shifts attention away from the perhaps dangerous behaviour of the parent seeking custody to that of the custodial parent. This person, who may be 
Não houve qualquer preocupação de Gardner com os graves danos psicológicos infligidos à mãe e às crianças em face das agressões praticadas pelo pai. Parece absurdo, mas o criador da expressão SAP teria aconselhado os pais (homens) a bater nos próprios filhos se estes reclamassem "do pai rejeitado", denunciam seus opositores ${ }^{22}$.

O embate acerca do tema acirrou-se verdadeiramente quando da tentativa de alguns de incluir a AP como "síndrome" junto ao DSM-5 (Diagnostic and Statistical Manual of Mental Diseases, Fifth Edition) ${ }^{23}$ e ICD-11 (International Classification of Diseases, Eleventh Edition) ${ }^{24}$.

Houve, em especial, sentida reação da comunidade científica internacional (notadamente psiquiátrica) quanto à inserção

attempting to protect the child, is instead presumed to be lying and poisoning the child. Fourth, Gardner believes that, particularly in serious cases, the relationship of an alienated child with the rejected parent will be irreparably damaged, probably ending for all time, unless immediate, drastic measures (custody transfer, isolation from the loved parent, and deprogramming) are taken. Here, too, reliable sources reveal that his theory is exaggerated, with all but unusual cases (for example, those appearing in violent families) resolving themselves as the children mature". BRUCH, Carol S., Parental Alienation Syndrome and Alienated Children - getting it wrong in child custody cases, p. 383/385. Tradução livre e adaptada.

22 No original: "Neither did Gardner (1992) pay sufficient attention to the psychological harm that could be caused by removing the child's psychological parent who has provided security and developmental growth for the child. Gardner's writings advocate breaking the parent-child bond on the identified alienator, who is treated as a mean, vicious, and hateful person without taking into account the detrimental effects on the child or parent. In a particularly compelling documentary, Gardner's own words advise parents to "beat" the child who complains about a rejected parent (Waller, 2008)". Tradução livre e adaptada.

23 Dicionário de Saúde Mental 5. a edição ou DSM-5 é um manual diagnóstico e estatístico feito pelaAssociação Americana de Psiquiatria para definir como é feito o diagnóstico de transtornos mentais. Usado por psicólogos, médicos e terapeutas ocupacionais. A versão atualizada saiu em maio de 2013 e substitui o DSM-IV criado em 2000. Desde o DSM-I criado em 1952, esse manual tem sido uma das bases de diagnósticos de saúde mental mais usados no mundo. In Wikipédia, consulta em 11/8/2014.

24 AClassificaçãoEstatísticaInternacionaldeDoençaseProblemasRelacionadoscom a Saúde, frequentemente designada pela sigla CID ou ICD (do inglês International Statistical Classification of Diseases and Related Health Problems) fornece códigos relativos à classificação de doenças e de uma grande variedade de sinais, sintomas, aspectos anormais, queixas, circunstâncias sociais e causas externas para ferimentos ou doenças. A cada estado de saúde é atribuída uma categoria única à qual corresponde um código, que contém até seis caracteres. Tais categorias podem incluir um conjunto de doenças semelhantes. 
da AP (ou SAP) como transtorno mental junto ao DSM-5, e isso por dois motivos centrais: primeiro, em face da possível estigmatização sofrida pelas crianças cujos pais enfrentam um divórcio conturbado e, segundo, em razão da provável utilização maliciosa de seu diagnóstico junto a processos judiciais que possuem alto grau de litigiosidade entre as partes.

A American Psychological Association foi uma das tantas e importantes entidades médicas que veementemente manifestou contrariedade à inclusão da AP no DSM, evidenciando o inequívoco antagonismo do círculo médico-científico à sua adoção como um diagnóstico/uma síndrome, pela escassez de pesquisas e evidências (empíricas, científicas ou clínicas) acerca da questão (AP e SAP):

"Uma das críticas apresentadas ao nosso propósito foi o argumento de que não há pesquisa suficiente para AP, SAP, transtorno de alienação parental (PAD), ou de alienação parental como problema relacional (PARP), para ser considerado um diagnóstico no DSM ou CID. Esta crítica é refletida no comunicado publicado pela Associação Americana de Psicologia: "a Associação Americana de Psicologia não tem posição oficial sobre "síndrome de alienação parental"... não há evidência na literatura psicológica de uma sindrome de alienação parental diagnosticável. ... Nos três artigos em apreço, Walker e Shapiro escreveram: "Não há ... corpo de literatura cientifica, empírica ou clínica para apoiar a construção de PAD” (Ref. 5, p. 279). Da mesma forma, Houchin et al. disseram: "Continua a haver uma escassez de evidências científicas de que a SAP (ou PAD) deve ser um diagnóstico psiquiátrico" (6 Ref., p 128). Pepiton et al. declararam: "Este livro é composto de opinião e relatórios anedóticos principalmente sem fundamento ... O livro falha completamente ao não fornecer qualquer documentação respeitante à pesquisa empírica apoiando tal condição ou diagnóstico e, em vez disso, mostra-se longa diatribe de uma pessoa que promove sua própria 
agenda apenas com anedotas e referências não científicas (7 Ref., p 252)”. 25

No mesmo sentido - e de maneira igualmente contundente e contrária a respeito do uso clínico e legal da SAP posicionou-se a Associação Espanhola de Neuropsiquiatria:

"Nos últimos anos em Espanha, como em outros países vizinhos, infiltraram-se nas decisões judiciais, sob a roupagem supostamente cientifica da SAP, argumentos para mudança de guarda ou outras ações legais de enorme repercussão na vida da criança e de sua família, argumentos esses, sem embargo, não aceitos pela ampla maioria dos profissionais ligados à área de saúde mental. Acreditamos que o sucesso do termo (SAP) no campo judicial se deve ao fato de possibilitar uma resposta simples (e simplista) a um grave problema que preocupa e satura os juizados de família, fornecendo argumentos pseudopsicológicos ou pseudocientíficos (Escuero, Aguilar e Cruz, 2008a, b) aos advogados daqueles genitores que discutem a guarda de seus filhos. Esta explicação pode ajudar a entender por que a expressão (SAP) tem sido aceita, apesar da ausência de rigor, sem quaisquer questionamentos. O risco atual de que tal "construção da realidade" também se infiltre nos sistemas de diagnóstico internacionais, como o DSM V, tem feito com que muitas associações e profissionais de diferentes países se manifestem contra essa hipótese. (...) Que a SAP, tal e

25 No original: "One of the criticisms of our proposals has been the argument that there is not enough research for PA, PAS, parental alienation disorder (PAD), or parental alienation relational problem (PARP), to be considered a diagnosis in $D S M$ or ICD. This criticism is reflected in the statement published by the American Psychological Association: "The American Psychological Association has no official position on "parental alienation syndrome."... There is no evidence within the psychological literature of a diagnosable parental alienation syndrome. In the three articles under consideration here, Walker and Shapiro wrote, "There is no... body of scientific, empirical, or clinical literature to support the construct of PAD" (Ref. 5, p. 279). Similarly, Houchin et al. said, "There remains a paucity of scientific evidence that PAS (or PAD) should be a psychiatric diagnosis" (Ref. 6, p 128). Pepiton et al. stated: "This book consists of mostly unsupported opinion and anecdotal reports... The book completely fails to provide documentation of any empirical research supporting such a condition or diagnosis and instead is long diatribe of a person promoting his own agenda with only anecdotal or unscientific references" (Ref. 7, p 252)". BERNET, Willian; BAKER, Amy J.L. Parental Alienation, DSM-5 and ICD-11: Response to Critics, p. 2. Tradução livre a adaptada. 
como a inventou Gardner, não possui nenhum fundamento científico e sua aplicação pelas Cortes Judiciais implica sérios riscos" 26 .

Com efeito, ao contrário do que dizem os gardneristas, a inclusão da AP no DSM (como "síndrome", passando a ser tida como SAP), não facilitará as pesquisas sobre o tema, inexistindo estudos científicos (verdadeiramente científicos, com seguimento de protocolo, teste das hipóteses, sindicância, debate com a comunidade científica etc.) que comprovem ou sugiram que a imposição à criança de convivência com o pai rejeitado melhore sua saúde mental ${ }^{27}$.

Dizem os opositores da "teoria", ainda, que a motivação daqueles que advogam em favor do reconhecimento da existência da SAP se dá, não raro, por interesses pessoais escusos (promoção, dinheiro, resolução de situações pessoais) e, por fim, que Richard Gardner passou a vida buscando autopromoção,

26 No original: "En los últimos años em España, lo mismo que en otros países de nuestro entorno, se ha ido infiltrado em las sentencias judiciales bajo la supuesta rúbrica científica del SAP argumentos para cambios de custodia $u$ otras acciones legales de enorme repercúsion para el niño e la familia; argumentos sin embargo no aceptados por una amplia mayoria de profesionales de salud mental. Creemos que el éxito que ha tenido el término en el campo judicial se debe a que da una respuesta simple (y simplista) a un grave problema que preocupa y satura los juzgados de familia, facilitando argumentos pseudo-psicológicos o pseudocientíficos (Escuero, Aguilar y de la Cruz, 2008 a,b) a los abogados de aquellos progenitores litigantes por la custodia de sus hijos. Esta explicación puede ayudar a entender por qué ha sido aceptado, pese a sua falta de rigurosidad, sin apenas cuestionamentos. El riesgo actual de que tal "construcción de la realidad" se infiltre también en los sistemas diagnósticos internacionales, como el DSM V, ha hecho que muchas asociaciones y profesionales de diferentes países se pronunciem en contra de este supuesto. (...) Que el SAP tal y cómo lo inventó Gardner no tiene ningún fundamento científico y si entraña graves riesgos su aplicación en la corte judicial". Revista de la Asociación Española de Neuropsiquiatria, p. 535-7. Tradução livre e adaptada.

27 No original: "As discussed, alienation is almost alleged when the child does not want to be with a parent when there does not appear to be any 'rational' reason for these feelings. Of course, the definition of "rational" in these cases remains totally subjective to the person making the evaluation. Although proponents of labeling these children with PAD claim that using this label will assist in treatment goals and techniques, there are no empirical data to support this position (Bernet, 2010). Using the definition put forward by the American Psychological Association (APA) which requires two scientific studies replicating each other, there are no empirically validated interventions that support evidence that forcing a child to be with an unwanted parent will promote mental health". Tradução livre e adaptada. 
autopublicando sua própria obra. Sustentam, por exemplo, que a PAD (parental alienation disorder) teria sido "projetada" para uso em casos de divórcio de alto conflito e que se devem examinar as possíveis motivações financeiras que podem influenciar as posições assumidas por aqueles engajados no debate (chegando ao ponto de afirmar, acidamente, que em relação à SAP "basta seguir o rastro do dinheiro" ${ }^{28}$.

Apontam os incontáveis divergentes de Gardner o descrédito dos testemunhos e laudos por ele produzidos em juízo, sendo comum a desconsideração de seu trabalho (e das teses que sustentam a SAP) pelos Magistrados, afirmando Paul J. Fink (um dos ex-presidentes da Associação Americana de Psiquiatria), por exemplo, que a SAP, como uma teoria científica, tem sido execrada por pesquisadores sérios em todos os Estados Unidos, concluindo que "julgado apenas por seus méritos, Dr. Gardner deve ser uma nota de rodapé patética ou um exemplo de padrões científicos pobres" 29 .

Também na Argentina tem-se repudiado, de forma resoluta e intransigente, a "teoria” de Gardner (SAP), posto que seu trabalho, permanentemente questionado pela comunidade científica, não se baseia em métodos de investigação padroni-

28 No original: "Walker and Shapiro attributed an ulterior motive to the mental health professionals who developed the proposal that PA be included in DSM-5. They said, "The proposed category of PAD is specifically designed for use during high-conflict divorce cases" (Ref.5, p.278). Along the same lines, Houchin et al. opined, "As with any heated controversy, one must examine the possible financial motivations that may influence the positions of those engaged in debate. Unfortunately, to get a good sense of PAS's support, one has only to follow the money trail" (Ref. 6, p. 129). They also said, "One has to wonder if some of the interest on the part of mental health practitioners supporting the inclusion of PAS or PAD in DSM-5 has more to do with economic self-interest than with any belief that it would lead to improved clinical practice" (Ref.6, p. 130)." BERNET, Willian; BAKER, Amy J.L., Parental Alienation, DSM:5, and ICD-11: Response to Critics, p. 5-6. Tradução livre e adaptada.

29 De acordo com Bruch, "in the few reported cases in which Gardner's proffered testimony was challenged or the validity of PAS was otherwise questioned, courts usually exclude his testimony and reliance on PAS" (p. 388). E ainda, "Dr. Paul J. Fink, past president of the American Psychiatric Association and president of the Leadership Council on Mental Health, Justice, and the Media, for example, has stated quite bluntly, 'PAS as a scientific theory has been excoriated by legitimate researchers across the nation. Judged solely on his merits, Dr. Gardner should be a rather pathetic footnote or an example of poor scientific standards" (p. 399). Em tradução livre e adaptada. BRUCH, Carol S., Parental Alienation Syndrome an Alienated Children - getting it wrong in child custody cases. 
zados (e, pois, não sindicáveis), nem foi submetido a estudos empíricos de validação. E o prova o fato de que seus trabalhos não foram aceitos para publicação em revistas científicas qualificadas. De se agregar que todos os seus livros foram publicados por uma editora de sua propriedade ${ }^{30}$.

A SAP, diz a Revista de la Asociación Española de Neuropsiquiatria, encontra-se desprovida de qualquer conteúdo científico, correspondendo à descrição que faz o próprio Gardner baseado em suas opiniões pessoais e autocitações. Assim, por exemplo, em um de seus artigos considerados "seminais", das 16 referências bibliográficas, 15 correspondem a autocitações de trabalhos do próprio autor ${ }^{31}$.

Obtemperam respeitados estudiosos, porém, que apesar de toda a evidência acerca da fragilidade da "teoria" de Gardner (chega a Associação Mundial de Psiquiatria a dizer que se trata de uma "invenção" acientífica destinada a mascarar o abuso sexual infantil, ao ponto de muitas associações médicas afirmarem ser a SAP nada mais que um mito), é ela comumente utilizada por advogados como argumento na disputa envolvendo a guarda das crianças, mesmo quando revelado pelos laudos técnicos estar o pai abusando sexualmente da criança ${ }^{32}$.

30 No original: “(...) sus trabajos han sido permanentemente cuestionados por la comunidad científica, dado que sus teorías no se basan en métodos de investigación estandardizados, ni han sido sometidos a estudios empíricos de validación. La prueba de ello es que ningún trabajo de Gardner ha sido aceptado para su publicación en una revista científica. Habría que agregar que todos sus libros han sido publicados por una editorial de su propriedad: Creative Therapeutics". CORSI, Jorge. El "síndrome de alienación parental", o el peligro que entrãnan las teorias pseudocientíficas como base de las decisiones judiciales, p. 2. Tradução livre e adaptada.

31 No original: "Las bases sobre las que se construye el "castillo en el aire" del SAP corresponden a la descripción que hace R. Gardner en 1985 basándose en sus opininones personales y en autocitas. En uno de sus artículos considerados "seminales", de 16 referencias bibliográficas, 15 corresponden a auto-citas de trabajos del proprio Gardner (2004)". Revista de la Associación Española de Neuropsiquiatria, p. 536. Tradução livre e adaptada.

32 No original: "Although many medical associations say parental alienation syndrome is a myth, it is commonly used to help gain custody of a child, even when evaluators say the parent is abusing the child. It's such a powerful legal tool that lawyers attend seminars on how best to use it". KEATING, G. (February 11, 2001). Group seeks reform for family court Bias against women alleged. San Gabriel Valley News (Pasadena, CA) in DALLAM, Stephanie. Tradução livre e adaptada. 
E tal fenômeno, destaca-se, também está a ocorrer no Brasil, como se verá em tópico próprio.

Em nível internacional, porém, a condenação daquilo que tem sido denominado pseudociência de Gardner chegou ao ponto de se qualificar como antiética a utilização, em laudos e perícias pelos profissionais da área da saúde, das expressões SAP e PAD (parental alienation disorder), em que pese a modificação do conceito de SAP ao longo dos anos, uma vez mantidas as suas premissas centrais no PAD, seu sucessor eufêmico. É importante advertir que o próprio Gardner, antes de cometer suicídio, propôs a retirada do termo "síndrome", o que parece ignorado por seus asseclas ${ }^{33}$.

33 No original: "In 1994, the American Psychological Association's Council of Representatives found that there were no empirical data to support PAS as a diagnosis and cautioned psychologists that it was unethical to use any diagnosis without supporting data. This pronouncement occurred after the Presidential Task Force on Violence and the Family, chaired by Walker, reviewed the available literature and took testimony from psychologists around the United States (c.f. APA, 1996). The concept of PAS has been modified during the past 20 years, and the idea of a syndrome has been dropped while the mostly untested clinical details originally proposed by Gardner remain as the core of PAD (Bernet, 2010). In fact, prior to Gardner's death, he, too, proposed dropping the "syndrome" requirement and only recommended introduction of parental alienation in the courts (Gardner, 2002)". (p. 276) "First and foremost, psychologists are required to base findings on empirically, scientifically, or clinically validated assessments. Since there is no such body of scientific, empirical, or clinical literature to support the construct of $P A D$, a psychologist who renders such a conclusion is immediately involved in ethically questionable behaviour (APA, 2002)". (p. 279) "Finally, and perhaps most important, is the harm that can come from forcing a child to have contact with an abusive or violent parent, following a finding that the other parent has alienated the child. Ethically, all mental health professionals are required to take reasonable steps to prevent harm where is reasonably foreseeable. Making a recommendation that a child spend time with a parent whom he or she fears based on a questionable finding of PAD clearly violates this ethical standard". Tradução livre e adaptada. 


\section{QUESTIONAMENTOS QUANTO AO PRECONCEITO DE GÊNERO, ADULTISMO E VULNERABILIDADE DA MÃE DETENTORA DA GUARDA. BACKLASH?}

Entidades internacionais de defesa das mulheres e das crianças têm há muito alertado acerca da prática de preconceito de gênero (em geral contra as mulheres), evidenciado em casos envolvendo acusações de violência doméstica e alienação parental. Denunciam que as Cortes de Justiça (entre elas as norte-americanas), mesmo hoje, tendem a minimizar as acusações de violência sejam elas físicas, sexuais ou psicológicas em desfavor de mulheres e crianças, privilegiando pais e maridos agressores. Alertam para a posição ainda agora fragilizada das mulheres, normalmente em desvantagem financeira e emocional perante seus ex-maridos e parceiros, o que acaba por ser determinante em discussões envolvendo divórcio, guarda e pensão alimentícia.

Elenca a literatura, assim, as inúmeras vantagens que possui o agressor quando da disputa judicial acerca da guarda e pensão alimentícia dos filhos, pois lançará ele mão, se necessário, dos argumentos relativos à alienação parental, destacando-se (1) sua normalmente maior capacidade econômico-financeira de custear um processo judicial (ao mesmo tempo que, paradoxalmente, diz não possuir condições para pagar uma pensão alimentícia adequada à criança), (2) a vantagem marcante sobre sua vítima em testes psicológicos, já que ela (a criança e/ou a mãe) é a única que foi traumatizada pelo abuso, (3) a capacidade de manipular os peritos judiciais (normalmente, dada a escassez de recursos humanos e financeiros, restringe-se a equipe de auxiliares do juízo, na melhor das hipóteses, aos assistentes sociais e psicólogos, assoberbados de demandas urgentes), que se tornam assim solidários para com o agressor, e (4) sua capacidade de manipular e intimidar as crianças a respeito das declarações prestadas ao perito (assistentes sociais, psicólogos) ${ }^{34}$. Muitos dos

34 No original: "A batterer who does file for custody will frequently win, as he has numerous advantages over his partner in custody litigation. These include, 1) 
agressores, diz-se, são hábeis manipuladores, apresentando-se como pais carinhosos, cooperativos, apontando o outro genitor (a vítima) como um incitador de conflitos, impulsivo ou excessivamente protetor ${ }^{35}$.

Com efeito, um dos principais argumentos utilizados pelos pais agressores, diante de mães "protetoras", é a de estarem elas alienando seus filhos. The National Organization for Women Foundation denuncia que as acusações de transtorno de alienação parental feitas por pais (ex-maridos) abusadores se dá com o claro propósito de que os Tribunais desconsiderem a denúncia materna de abuso sexual ou físico praticado contra a criança e, com isso, buscam "negociar" pensão alimentícia e guarda compartilhada dos filhos ${ }^{36}$.

Observam os argutos críticos de Gardner que, nos últimos anos, o uso da expressão SAP tem sido estendida de forma dramática para incluir todos os casos nos quais a criança se recusa a visitar o genitor que não possui a guarda, mesmo que a recusa ou resistência tenha como origem suspeitas de abuso sexual. Nada disso aparentemente importava a Gardner, porém, pois seu objetivo era verificar se o genitor-alienante (?) e o filho estavam mentindo, e não se o outro genitor-alienado (?) era

his typical ability to afford better representation (often while simultaneously insisting that he has no money with which to pay child support), 2) his marked advantage over his victim in psychological testing, since she is the one who has been traumatized by the abuse, 3)his ability to manipulate custody evaluators to be sympathetic to him, an 4) his ability to manipulate and intimidate the children regarding their statements to the custody evaluator(p.5)". CANCROFT, L.R. (1998). Understanding the batterer in custody and visitation disputes. In DALLAM, Stephanie. Tradução livre e adaptada.

35 DALLAM, Stephanie, citando Goelman, D.M., Lehrman, F.L., \& Valent, R.L. (Eds.). (1996) The impact of domestic violence on your legal practice: A lawyer's handbook. Washington D.C.: ABA Commission on Domestic Violence. No original: "be aware that many perpetrators of domestic violence are facile manipulators, presenting themselves as caring, cooperative parents and casting the abused parent as a diminished, conflict-inciting, impulsive or over-protective parent". Tradução livre e adaptada.

36 No original: "This accusation (of parental alienation disorder) is made by abusive ex-husbands and is intended to cause the courts to disregard mothers 'claims of fathers' physical or sexual abuse in an effort to gain the fathers' full of joint custody". BERNET, William; BAKER, Amy J.L. Parental Alienation, DSM-5 and ICD-11: Response to Critics, p. 5. Tradução livre e adaptada. 
mendaz ou possuía comportamento que pudesse explicar a aversão da criança. O "tratamento" prescrito por Gardner para o caso consistia em transferir a guarda da criança - do genitor "alienante" ao rejeitado -, a fim de proceder à "desprogramação" do infante (utilizava ele também a expressão "lavagem cerebral reversa") $)^{37}$.

De fato, vítimas de violência doméstica (mulheres e crianças) as mais das vezes mostram-se menos estáveis emocionalmente, pois são elas, justamente, as que sofrem os efeitos psicológicos do trauma do abuso, possuindo ainda, em grande parte dos casos, menor capacidade financeira (inclusive no que se refere à moradia) ${ }^{38}$.

Os escritos de Gardner, inclusive sobre a SAP, dizem autores de nomeada, são claramente discriminatórios e preconceituosos contra a mulher. Esta parcialidade de gênero infecta a síndrome, mostrando-se poderosa ferramenta para desqualificar a credibilidade das mulheres que denunciam abuso sexual infantil. Isto porque a SAP perpetua e exacerba a discriminação de gênero contra a mulher, colocando muito mais sombra

37 No original: "In recent years, use of term PAS has been extended dramatically to include cases of all types in which a child refuses to visit the noncustodial parent, whether or not the child's objections entail abuse allegations. Although Dr Gardner sometimes states that his analysis does not apply to cases of actual abuse, the focus of his attention is directed at discerning whether the beloved parent and child are lying, not whether the target parent is untruthful or has behaved in a way that might explain the child's aversion. His recommended treatment for serious case is to transfer custody of the child from the beloved custodial parent to the rejected parent for deprogramming. This may entail institutional care for a transitional period, and all contact, even telephone calls, with the primary caregiver must be terminated for 'at least a few weeks'. Only after reverse- brainwashing may the child slowly be reintroduced to the earlier custodian through supervised visitation". BRUCH, Carol S., Parental Alienation Syndrome and Alienated Children - getting it wrong in child custody cases, p. 381. Tradução livre e adaptada.

38 No original: "victims of domestic violence often appear much less stable, suffering the psychological effects from the trauma of the abuse, and are often "less likely to have adequate financial resources and stable housing, and (are) more likely to remove the children from their current educational environment, home, and community". JACK, Jennifer, Child custody and domestic violence allegations: New York's approach to custody proceedings involving intimate partner abuse, p. 904. Tradução livre e adaptada. Tradução livre e adaptada. 
do que luz sobre este difícil tema ${ }^{39}$, uma vez que ideologiza o conceito, desvinculando o direito de convivência da vontade dos filhos. Quer dizer, há uma forte ênfase nos direitos do pai, em detrimento dos direitos de proteção dos filhos que possam ser exercidos pela mãe ${ }^{40}$.

No contexto, revelam abalizadas pesquisas científicas que o litígio judicial pode tornar-se, ele próprio, um veículo de ampliação-manutenção do controle e autoridade praticados pelos agressores e abusadores de crianças em face de suas vítimas. Embora não haja qualquer evidência de uma maior incidência de falsas acusações de abuso infantil e violência doméstica quando da disputa da guarda/visitação há, por parte dos operadores do sistema de justiça (juízes, advogados, promotores, servidores, peritos), excessiva desconfiança acerca da veracidade de tais denúncias promovidas pelas vítimas (talvez até devido à inimaginável brutalidade dos atos), o que as revitimiza novamente, agora com o beneplácito ou conivência do próprio sistema de justiça ${ }^{41}$.

39 No original: “...en mi opinión, muchos de los escritos de Gardner, incluyendo su Parental Alienation Syndrome, son discriminatorios y perjuiciosos contra la mujer. Esta parcialidad de género "infecta" el síndrome, y logra una poderosa herramienta para menoscabar la credibilidad de las mujeres que denunciam abuso sexual infantil. Porque el PAS perpetúa y exarceba la discriminación de género contra la mujer, yo considero que el síndrome arroja mucha más sombra que luz sobre este difícil tema...". MYERS, E.B., apud CORSI, Jorge. El "síndrome de alienación parental", o el peligro que entrañan las teorias pseudocientificas como base de las decisiones judiciales, p. 4. Tradução livre e adaptada.

40 No original: "En la aplicación ideologizada del concepto, la responsabilidad por el impedimento es adjudicada en la casi totalidad de los casos a la madre, pasando por alto las decisiones judiciales fundamentadas em la conducta abusiva del padre, y desvinculando el derecho de convivencia de la voluntad de los hijos e hijas. Es decir, hay un fuerte énfasis en los derechos del padre, en detrimento de los derechos a la protección de sus hijos/as que pueda ejercer la madre". CORSI, Jorge. El "síndrome de alienación parental", o el peligro que entrañan las teorias pseudocientificas como base de las decisiones judiciales, p. 2-3. Tradução livre e adaptada.

41 No original: "Research indicates that custody litigation can become a vehicle whereby batterers and child abusers attempt to extend or maintain their control and authority over their victims after separation. Although, research has not found a higher incidence of false allegations of child abuse and domestic violence in the context of custody/visitation, officers of the court tend to be unreasonably suspicious of such claims and that too often custody decisions are based on ban science, misinterpretation of fact, and evaluator bias. As a result, many abused 
Tanto assim que, conforme literatura especializada, 97\% das mães afirmam ignorarem ou minimizarem os Tribunais as denúncias de abuso sexual praticado pelo genitor-agressor contra a criança, sendo elas (as mães) punidas por tentar proteger seus filhos, ao passo que significativos $45 \%$ das genitoras se dizem rotuladas como portadoras da $\mathrm{SAP}^{42}$. E mais e assustadoramente: embora falsas acusações de abuso sexual praticadas pelas mães no decorrer de processos judiciais relativos à guarda de crianças não sejam comuns, tendem os advogados a aconselhar as mulheres a não levantar acusações de abuso sexual, mesmo que verdadeiras, a fim de não colocar em risco suas chances de permanecer com a guarda dos filhos ${ }^{43}$. Assim, são as mães orientadas por seus advogados e pelo juiz a não se oporem à visitação dos pais, mesmo quando se sentirem inseguras em relação a isso ou até diante do protesto dos filhos ${ }^{44}$.

women and their children find themselves revictimized by the justice system after separation". DALLAM, Stephanie (diretora de pesquisa do The Leadership Council on Child Abuse \& Interpersonal Violence, Baltimore, USA), Are "good enough" parents losing custody to abusive ex-partners? Tradução livre e adaptada.

42 No original: "97\% of the mothers reported that court personnel ignored or minimized reports of abuse and that they were punished for trying to protect their children. 45\% of the mothers say there labeled as having Parental Alienation Syndrome (PAS)". STAHLY G.B; KRAJEWSKI L.; Loya, B.; GERMAN G.; FARRIS W.; HILSON, N.; VALENTINE, J. (2004). Protective Mothers in Child Custody Disputes: A Study of Judicial Abuse. In Disorder in the Courts: Mothers and Their Allies Take on the Family Law System (a collection of essays) in DALLAM, Stephanie, Are "good enough" parents losing custody to abusive ex-partners? Tradução livre e adaptada.

43 No original: "noting that, although research indicates that false accusations of sexual abuse during child custody disputes are not a common occurrence, lawyers tend to advise women not to raise allegations of sexual abuse because they will jeopardize their chances of receiving custody". Law Society of British Columbia Gender Bias Committee (1992). Gender equality in the justice system, Volume II. Author. (as cited in: Penfold, S.P. (1997). Questionable beliefs about child sexual abuse allegations during custody disputes. Canadian Journal of Family Law, 14, 11-30) in Stephanie Dallam, Are "good enough" parents losing custody to abusive ex-partners? Tradução livre e adaptada.

44 No original: "mothers are told by their lawyer, the law guardian or the judge not to oppose visitation, even when they felt it was unsafe or when their children protested". The Voices of Women Organizing Project (VOW) 2008 Justice Denied: How Family Courts in NYC Endanger Battered Women and Children. Brooklyn, NY: Battered Women's Resource Center in Stephanie Dallam, Are "good enough" parents losing custody to abusive ex-partners? Tradução livre e adaptada. 
Bem a propósito, colhe-se o posicionamento da American Psychological Association:

\begin{abstract}
"Neste contexto, o genitor não violento pode ficar em desvantagem quando o comportamento protetivo por ele exercido contra o genitor que abusa dos filhos for interpretado como um sinal de instabilidade. Avaliadores psicológicos não treinados em violência doméstica podem contribuir para este processo, ignorando ou minimizando a violência e conferindo inadequados rótulos patológicos para as respostas femininas à vitimização crônica. Termos como 'alienação parental' podem ser usados para culpar as mulheres pelo fundado medo das crianças ou pela raiva sentida contra seu violento pai" ${ }^{35}$.
\end{abstract}

O preconceito de gênero aí existente vem fortemente criticado pela Associação Espanhola de Neuropsiquiatria, a qual se manifesta clara e fragorosamente contra a adoção clínica e legal da SAP. Deveras, o "viés de gênero" mostra-se escancarado na origem da SAP. Cônjuges "mães alienantes" são, na visão de seus defensores, as mulheres que odeiam homens, e qualquer tentativa da mulher de se rebelar implica o risco de retirada da guarda de seus filhos, constituindo-se eventual resistência materna em mais uma prova da alienação por ela patrocinada e da "programação" a que submetida a criança. Qualquer ensaio de protesto caracteriza o diagnóstico inventado por Gardner, pois constitui (o protesto) amostra dos sintomas da "programação" utilizada pela mãe para afastar o filho do pai. Como concebida, a SAP jamais poderá ser refutada, porque qualquer movimento de refutação por si só confirma o diagnóstico, "a

45 No original: "In this context, the nonviolent parent may be a disadvantage, and behaviour that would seem reasonable as a protection from abuse may be misinterpreted as a sign of instability. Psychological evaluators not trained in domestic violence may contribute to this process by ignoring os minimizing the violence and by giving inappropriate pathological labels to women's responses to chronic victimization. Terms such as 'parental alienation' may be use to blame the women for the children's reasonable fear or anger toward their violent father (p.100)". American Psychological Association (1996). Report of the American Psychological Association presidential task force on violence and the family. Washington, DC in DALLAM, Stephanie. Are "good enough" parents losing custody to abusive ex-partners? Tradução livre e adaptada. 
verdade". Trata-se de uma engrenagem perversa, pois qualquer ação visando a proteção da criança do outro genitor se converte em mentira da mãe e em nova tentativa de "programação"46.

Com efeito, inúmeras instituições têm denunciado a propositura de litígios visando a alteração da guarda, instaurados sob a alegação de AP ou SAP mas que, na verdade, buscam forçar acordos a respeito de bens, visitação e pensão alimentícia.

As mães, de forma geral, têm entre seus maiores temores a perda da guarda dos filhos. Já aqueles pais que as requerem como tática de barganha (bens, alimentos, visitas) nada têm a temer ou perder. Aliás, ao contrário da percepção pública, os homens são muito bem-sucedidos quando de fato procuram o Poder Judiciário com a sincera intenção de obter a guarda dos filhos do casal, nomeadamente quando a mãe não apresenta condições para tanto ${ }^{47}$. Doutro lado, pesquisas revelam que a adoção acrítica e generalizada da SAP tem implicado a violação

46 No original:"El sesgo de género en las descripciones del SAP es innegable. La mayoria de los cónyuges "alienadores" son en su opinión "mujeres que odian a los hombres". Cualquier intento de estar por rebelarse ante el riesgo de retirada de custodia de su hijo, se convierte en nuevas pruebas de la alienación y de la programación a que someten al hijo. Por otra parte cualquier intento de protesta del niño o niña se convierte, por mor de los criterios diagnósticos que Gardner inventó, en nuevos síntomas de su programación. Incluso los terapeutas que argumentan en contra del SAP se convierten también, según Gardner, en sujetos vulnerables a la programación que entram a formar parte de sua especie de "folie à trois", en palabras, del proprio Gardner (1999). Es decir, en contra de cualquier planteamento científico, el SAP se construye de modo que nunca pueda ser refutado porque cualquier intento de refutación lo convierten, por si mismo en verdadero. Se desoyen con base al SAP las protestas o acusaciones del niño (y de la madre) de maltrato o abuso. Aunque Gardner especifica que en caso de abuso no se debe de diagnosticar de SAP, el riesgo de dejar a un niño cuyas quejas son descalificadas y no escuchadas por considerarlas producto de una programación, en manos de un progenitor maltratador es muy alto. A ello se suma el que los intentos de proteger al niño por parte del otro progenitor se convertien en mentiras y nuevos intentos de "programación". Se deja en manos de un potencial maltratador a un niño aislándolo de su único vínculo de protección". Revista de la Asociación Española de Neuropsiquiatria, p.536-7. Tradução livre e adaptada.

47 No original: "Many men file proceedings to contest custody as a way of forcing an advantageous property settlement. Contrary to public perception, men are quite successful in obtaining residential custody of their children when they actually seek it". Report of the Florida Supreme Court Gender Bias Study Commission Executive Summary (March 1990) http://www.flcourts.org/sct/sctdocs/bin/bias.pdf in DALLAM, Stephanie. Are "good enough" parents losing custody to abusive expartners? Tradução livre e adaptada. 
sistemática dos direitos humanos pelos próprios Tribunais, inclusive a falha na proteção de mulheres vítimas de violência e crianças vítimas de abuso, dispensando-lhes tratamento discriminatório e degradante e negando-lhes o "devido processo legal"48.

E a desconsideração/mitigação das manifestações de contrariedade das crianças à visitação - tomando-se como regra a negativa desfundamentada - em consequência da alienação parental traz à tona, no meio acadêmico, além das discussões a respeito do preconceito de gênero e da maior vulnerabilidade das mães detentoras da guarda, o debate acerca de dois outros fenômenos, o adultismo e o que se conhece por backlash.

Diz-se adultismo

"o sistema de crenças que, introduzindo uma estrutura rígida de hierarquias entre adultos e crianças, entende estas (as crianças) como objeto de adestramento, e não como sujeitos de direitos. A 'síndrome de alienação parental' pressupõe meninos e meninas como entidades passivas suscetíveis de serem moldados em seus pensamentos e sentimentos por adultos mal-intencionados que lhes 'introduzem' ideias sem que conte sua própria percepção da realidade. Esta imagem da infância não vai somente na direção oposta de todos os estudos cientificamente validados dentre da psicologia evolutiva, mas contradiz profundamente o espírito da Convenção Internacional dos Direitos da Criança"49.

48 No original: "The research found widespread adoption of "parental alienation syndrome", and found "a consistent pattern of human rights abuses" by family courts, including failure to protect battered women and children from abuse, discriminating against and inflicting degrading treatment on battered women, and denying battered women due process. Histories of abuse of mother and children are routinely ignored or discounted". Human Rights Tribunal on Domestic and Child Custody sponsored by Battered Mothers'Testimony. Project based at the Wellesley Centers for Women in Massachusetts (2002) in DALLAM, Stephanie. Are "good enough" parents losing custody to abusive ex-partners?. Tradução livre e adaptada.

49 No original: "al sistema de creencias que, introduciendo una estructura rígida de jerarquias entra adultos $Y$ niños/as, entiende a estos/as últimos/as como objetos de adiestramento y no como sujeitos de derechos. El "síndrome de de 
Denuncia Corsi, também, forte tendência ao backlash ${ }^{50}$, o conhecido movimento conservador, impulsionado por facções mumificadas da igreja e políticos de direita, intolerantes com o avanço das reivindicações dos direitos dos setores tradicionalmente marginalizados, como as mulheres, os meninos e as meninas.

De fato e como sabido, trata-se de um movimento político que nasce como resposta às conquistas alcançadas pelo feminismo no reconhecimento dos direitos das mulheres e na visibilidade e sanção pública da violência baseada no gênero. Em outras palavras, sobressai como uma reação tendente a manter o status quo promovido pela ideologia patriarcal, empregando para isso o questionamento das garantias outorgadas ao gênero feminino. Cuida-se de uma reação extrema, produto do descontentamento de certos grupos de homens diante das mudanças produzidas pelo feminismo não só em torno do tradicional papel destinado às mulheres, como também da discussão respeitante ao abuso sexual infantil.

alienación parental" presupone a los niños y a las niñas como entidades passivas susceptibles de ser moldeadas en sus pensamientos y sentimientos por adultos malévolos que les "introducen" ideas sin que cuente su propia percepción de realidad. Esta imagem de la niñez no solamente va en la dirección oposta de todos los estudios cientificamente validados dentros de la psicologia evolutiva, sino que contradice profundamente el espiritu mismo de la Convención Internacional por los Derechos de la Niñez". CORSI, Jorge. El "síndrome de alienación parental", o el peligro que etrañan las teorias pseudocientíficas como base de las decisiones judiciales, p. 5. Tradução livre e adaptada.

50 No original: "El backlash es un movimiento conservador que intenta retroater el conocimiento logrado acerca del problema del abuso sexual infantil a la etapia previa del ocultamiento y el secreto. Es impulsado por sectores tales como la iglesia y los sectores políticos de derechas, intolerantes con el avance en las reivindicaciones de los derechos de los sectores tradicionalmente marginados, como las mujeres, los niños e las niñas. Mientras se trate de casos que involucren a sectores socioeconómicamente excluidos, la reacción no se hace sentir. Pero comienza a adquirir virulencia quando los casos denunciados involucran a personas cercanas a ámbitos de poder (jerarcas de la iglesia, empresarios, políticos). Y es a estos sectores que las teorías pseudocientíficas de Gardner les han venido como anillo al dedo. Ler permiten justificar sus abusos, contraatacando con denuncias de falsas denuncias, con insistencia en el concepto de "alienación parental" (que en realidad lo limitan a una "alienación marental") y descalificando los testimonios de los ninõs e las niñas. Ni más ni menos que una reacción tendiente a conservar un poder que perciben minguante". CORSI, Jorge. El "síndrome de alienación parental", o el peligro que etrañan las teorias pseudocientíficas como base de las decisiones judiciales, p. 5-6. Tradução livre e adaptada. 
Nestes casos (de abuso sexual infantil), diz a literatura que na década de 1990, especialmente nos Estados Unidos, consolidaram-se posicionamentos ideológicos reacionários à defesa dos direitos humanos das crianças, havendo dois grupos distintos: (1) o primeiro grupo que integra o backlash inclui pais que foram acusados de cometer abuso sexual contra seus filhos, alguns peritos (especialmente da área privada) e pais divorciados. Neste grupo também se encontram alguns advogados que recebem altas somas em dinheiro para reunir bibliografia que apoie seus argumentos e lhes permitam defender os abusadores; (2) o segundo grupo que integra o backlash é composto por alguns experts que reúnem alguma literatura não científica (argumentos estandardizados) mas veem esses argumentos como científicos ${ }^{51}$.

51 No original: "De acordo con Faludi (1991) Backlash es un término utilizado para describir un movimiento político que nace como respuesta a los logros alcanzados por el feminismo en el reconocimiento de los derechos de las mujeres y en la visibilización y sanción pública de la violencia baseada en género. En otras palbras, sobresale como una reacción tendiente a mantener el status quo promovido por la ideologia patriarcal empleando para ello el cuestionamento de las garantías otorgadas al género femenino". "Para Faludi (1991), el Backlash constituye una reacción extrema, un contra-movimiento que nace alrededor de los años 1980, producto del descontento de ciertos grupos de hombres ante los cambios producidos por el feminismo en torno al rol tradicional de las mujeres". De esta manera, debe comprenderse el Backlash como una forme de resistencia ante el reconocimiento social de los derechos de las mujeres, ya que nace frente a las luchas por la emancipación femenina y en respuesta al problema, tanto de la violencia basada en género, como del abuso sexual infantil." "El caso particular del abuso sexual infantil, Finkellor (citado por Batres, 2010), también comparte la apreciación de que en la década de los años 1990, en Estados Unidos se consolidaron una serie de posicionamientos ideológicos reaccionarios a la defensa de los derechos humanos de los niños/niñas (Backlash), cuya presentación y cualidades divide en dos grupos: (1) el primer grupo que integra el backlash incluye a padres que han sido acusados de abuso sexual, a algunos peritos expertos, especialmente del área privada y a padres divorciados. También se encuentran aquí algunos abogados que reciben altas sumas de dinero por reunir literatura y argumentos que apoyen sus razionamentos y les permitan defender a los abusadores (...) (2) El segundo grupo que integra el backlash está compuesto por algunos "expertos" que han reunido alguna literatura no científica (argumentos estandarizados) pero ven esos razionamentos como científicos (Batres, 2010, 2-9)". "Así, el Backlash se ha expandido por medio de diversas derivaciones, algunas de ellas son: el surgimiento de las asociaciones de padres separados, el síndrome de alienación parental (SAP) y el síndrome de falsas memorias (SFM); estas dos últimas variantes han incursionado en la esfera judicial de muchos países (Batres: 2010), originando gran confusión en los casos de abuso sexual y culminando en muchas ocasiones tanto en la desestimación, como en la absolución de los ofensores sexuales (Bruch, 2002; Rivera \& Fields, 2003; Pauluzzi, 2007; Ministerio Público de Costa Rica, 2008; Paz, 2008; Claramunt, 2009)". VARGAS, Andrés Castillo; BADILLA, Ivannia 
O backlash tem-se expandido por meio de diversas derivações, como o surgimento das associações de pais separados, a SAP e a síndrome de falsas memórias (SFM), estas últimas incursionando na esfera judicial de muitos países, gerando enorme confusão nos casos de abuso sexual e culminando, em muitas ocasiões, na absolvição dos ofensores sexuais.

Enquanto se tratava de hipóteses envolvendo setores socioeconômicos excluídos, a reação não se fez sentir. Mas começa a adquirir virulência quando os casos denunciados passam a envolver pessoas próximas ao centro do poder (hierarcas da igreja, empresários, políticos). E é a estes setores que as teorias pseudocientíficas de Gardner têm servido como anel ao dedo. Permite-lhes justificar seus abusos, contra-atacando com denúncias de falsas denúncias, com insistência no conceito de "alienação parental" (que na realidade fica limitada a uma "alienação marental"), desqualificando os testemunhos dos meninos e meninas acerca das violações de que são vítimas. Nem mais nem menos que uma reação tendente a conservar um poder que percebem minguante. E este inadjetivável retrocesso encontra-se em pleno vigor também em nosso sistema legal no que se refere aos "pais protetores", aqueles que agem no sentido de preservar seus filhos de abusos, sejam eles físicos ou sexuais. Em torno disso, e para desmoralizá-los, foi-se construindo o mito de que as mães apresentam falsas alegações de abuso sexual ou físico (ou violência doméstica), o que se daria, curiosamente, em milhões de casos, e apenas com o intuito de privar os pais da convivência com os filhos, alienando-os ${ }^{52}$.

Chinchilla. Bachlash y Abuso Sexual Infantil: la emergencia de nuevas amenazas a la protección de los derechos humanos de las personas menores de edad. Tradução livre a adaptada.

52 No original: "There is a backlash in full force in our legal system against protective parents. "Protective parents" are those acting to protect their children from abuse, be it physical or sexual. Protective parents are, much more often than not, mothers. The Fathers Rights Movement has been built on the myth that evil mothers lodged false allegations of sexual or physical abuse or domestic violence against millions of fathers just to deprive and alienate them from their children". ROCKEY, Arlaine. (2003). Custody Cases: Protecting Children from Sexual Abuse. in DALLAM, Stephanie. Are "good enough" parents losing custody to abusive ex-partners? Tradução livre e adaptada. 


\section{REVERSÃO DA GUARDA: PUNIÇÃO PARA O "ALIENANTE" OU PARA A CRIANÇA?}

Walker, Brantley e Rigsbee ${ }^{53}$ alertam que a aceitação incondicional da SAP e o desejo de "punição severa" às supostas alienantes, entre elas a reversão da guarda, acabam por desconsiderar o impacto ("danos graves", dizem eles) de tais medidas, a longo prazo, no desenvolvimento das crianças, inexistindo evidência científica de que em casos de acusações cruzadas (abuso sexual x alienação) seja a postura da suposta alienante a causa do comportamento desinteressado da criança em relação ao outro genitor.

Denuncia a Associação Espanhola de Neuropsiquiatria aquilo que o próprio Gardner denominou de "terapia da ameaça": "A terapia que propõe Gardner para acabar com a suposta 'programação' e que ele mesmo denominou de 'terapia da ameaça' fecha qualquer saída à criança vítima de abusos de escapar da situação temida. Ameaçar proibir ou privar as visitas ao outro genitor (normalmente a mãe) com o qual a criança possui o vinculo mais estreito força a criança a aceitar a relação com o genitor litigante" 54 .

53 No original: "Although some mental health professionals and child custody evaluators, attorneys, and judges have been quick to accept and admit PAS as evidence in these disputes, especially in those that have cross-complaints alleging family violence, there has been no consistent empirical or clinical evidence that PAS exists or that the alienator's behaviour is the actual cause of the alienated child's behaviour towards the target parent. It is argued here that the PAS construct itself is flawed and its use by custody evaluators to justify placement with the rejected parent may result in more serious damage to the child who is taken away from the parent to whom the child has bonded. These authors suggest that the PAS argument has been accepted by some courts that seem almost eager to punish the so-called alienating parent without regard for the immediate or long-term impact on the child". WALKER, L.E.; BRANTLEY, K.L.; RIGSBEE, J.A.; (2005). A Critical Analysis of Parental Alienation Syndrome an its Admissibility in the Family Court. Journal of Child Custody, 1(2), 47-74 in DALLAM, Stephanie. Are "good enough" parents losing custody to abusive ex-partners? Tradução livre e adaptada.

54 No original: "La 'terapia' que propone Gardner para acabar con la supuesta 'programación' y que él mismo denominó 'terapia de amenaza' cierra cualquier salida a un niño/a víctima de abusos de escapar de la situación temida. Amenazar con encarcelar o quitar las visitas al cònyuge (usualmente la madre) con quien el niño tiene el vínculo más estrecho, fuerza a la niña/o a aceptar la relación con el progenitor litigante". Revista de la Asociación Española de Neuropsiquiatria, p. 537. Tradução livre e adaptada. 
Mesmo os mais ardorosos defensores das teses de Gardner advogam ser necessário maior estudo (quantitative research) para que haja consenso a respeito do diagnóstico da SAP. Reconhecem que a questão é por demais delicada e, portanto, somente com base em critérios rígidos e a partir da existência de um corpo de profissionais treinados na sua identificação é que poderá ser evitado/identificado seu uso malicioso. $\mathrm{O}$ consenso sobre o diagnóstico é a forma correta de prevenir a utilização indevida de alegações de AP, até porque se mostra relativamente fácil para os genitores-agressores afirmar que seus filhos têm sido manipulados pelo outro genitor, uma vez que não existe uma definição minimamente uniforme de AP. Agregue-se a isso o fato de que profissionais de saúde mental não possuem suficientes experiência e conhecimento em relação ao diagnóstico de $\mathrm{AP}^{55}$.

Contra a transferência de guarda do filho ao genitor acusado de abuso e cessação das visitas ao genitor apontado como promotor da alienação (pilares da terapêutica de Gardner) posicionam-se inclusive aqueles que defendem as "teorias" da SAP, havendo quem, de maneira mais enfática, chame o conjunto da obra de Gardner de junk science (pseudo science) ${ }^{56}$.

55 No original: "One way to prevent the misuse of PA by abusive (men or women) is to have consensus regarding the diagnosis. An abusive parent claiming that a child refusing visitation was alienation would find it difficult to show that the child manifested the behavioral symptoms required for the diagnosis of PA. However, it is relatively easy for abusive parents to claim that their children have been manipulated if there is no uniform definition of $P A$, and mental health professionals remain untrained regarding the identification and differential diagnosis of PA". BERNET, William; BAKER, Amy J.L.. Parental Alienation: DSM-5, and ICD-11: Response to Critics, p.5. Tradução livre e adaptada.

56 No original: "Even therapists who accept PAS theory have advised against custody transfers to no avail in some reported cases in which seems judges have implemented Gardner's views on their own initiative. An electronic search for all reported US cases between 1985 and February 2001 employing the term "parental alienation syndrome" revealed that PAS was present, although far fewer were willing to recommend that custody be transferred and that contact with the primary custodian be terminated." (...) "High conflict families are disproportionately represented, of course, among the population of those contesting custody and visitation. These cases commonly involve domestic violence, child abuse, and substance abuse. Many parents are angry, and a broad range of visitation problems occurs. Dr. Gardner's description of PAS may well remind parents, 
Não há quem ponha em dúvida que o interesse a preponderar deva ser, sempre, o da criança, o que não deve ser confundido com a necessidade de afeto do próprio genitor ${ }^{57}$.

Por isso, em casos de divórcio conturbado envolvendo crianças (visitação, alimentos), mostra-se absolutamente imprescindível e necessária a realização de estudo social e avaliação psicológica e, em alguns casos, psiquiátrica em todos os envolvidos, buscando determinar os reais motivos a fundamentar a acusação de alienação parental, isto é, se se está diante de verdadeira AP ou de legítimo e momentâneo desinteresse da criança em conviver mais estreitamente com o genitor não guardião.

Daí a aflitiva advertência proposta pela AEN - Asociación Española de Neuropsiquiatria ${ }^{58}$ :

therapists, lawyers, mediators, and judges of these frequently encountered emotions, and this may help to explain why his audience has often accepted PAS without question. The overwhelming absence of careful analysis and attention to scientific rigor these professionals demonstrate, however, is deeply troubling. As the following discussion reveals, this carelessness has permitted what is popularly termed junk science (pseudo science) to influence custody cases in ways that are likely to harm children". BRUCH, Carol S. Bruch, Parental Alienation Syndrome and Alienated Children - getting it wrong in child custody cases, pag 383. Tradução livre e adaptada.

57 Yussef Said Cahali in Divórcio e Separação. 10a ed. São Paulo: Revista dos Tribunais, 2002, p. 930-1.

58 No original: "Que las complejas y con frecuencia violentas, o cuanto menos altamente conflictivas dinámicas familiares que abocan en un litigio por la custodia de un menor, tienen que ser estudiadas específicamente es decir, caso por caso. Que el profesional de salud mental no puede ocupar el papel de dictar la verdad ou falsedad de un asunto, aspecto que corresponde al juzgado. Pero que a un tiempo, en los juzgados no deben emplearse por los equipos técnicos adscritos, y si son requeridos, por profesionales de salud mental, constructos tales como los contenidos en el SAP (ya sea bajo esta rubrica terminológica $u$ otra) por su origen conceptual retórico más en ningún caso científico, y por ello con un enorme potencial de daño sobre menores y adultos privados de toda possibilidad de defensa (pues siendo "diagnosticados" todo intento de defensa se convierte en autoconfirmación del diagnóstico asignado). Que los argumentos que los profesionales de salud mental les aportemos a los profesionales de justicia deben basarse en literatura científicamente contrastada y no en meras repeticiones de recetas simplistas de un caso extrapolado a otro. Que se haga una difusión en círculos profesionales de salud mental y de justicia sobre cómo se llegó a la construcción de este supuesto síndrome de las graves consecuencias de su aplicacción y de las recomendaciones de trabajo coordinado entre campos profesionales de la salud mental y de la justicia. Que se haga una difusión en círculos profesionales de salud mental y de justicia sobre cómo se llegó a la 
1. Que as complexas e, com frequência, violentas, ou quando menos, altamente conflitivas dinâmicas familiares que surgem em um litígio judicial em que se discute a guarda de um menor devem ser estudas especificamente, isto é, caso a caso.

2. Que o profissional de saúde mental não pode ocupar o papel de dizer a verdade ou falsidade de um assunto, pois que tal corresponde ao Juiz. Mas, ao mesmo tempo, que não seja esquecido por todos o enorme potencial de danos causados em crianças e adultos privados de toda possibilidade de defesa (pois sendo "diagnosticados" com SAP, toda tentativa de defesa se transforma em autoconfirmação do diagnóstico a ela atribuído).

3. Que os argumentos que os profissionais de saúde mental aportem nos autos judiciais devem basear-se em literatura cientificamente contrastada e não em meras repetições de receitas simplistas de um caso extrapolado a outro.

4. Que se faça a difusão nos círculos profissionais de saúde mental e da justiça sobre como se chegou à construção desta suposta "síndrome" (SAP), das graves consequências de sua aplicação e as recomendações de trabalho coordenado entre os profissionais da saúde mental e da justiça.

construcción de este supuesto síndrome de las graves consecuencias de su aplicacción y de las recomendaciones de trabajo coordinado entre campos profesionales de la salud mental y de la justicia". Revista de la Asociación Española de Neuropsiquiatria, p. 537-8. Tradução livre e adaptada. 


\section{NECESSIDADE DE AVERIGUAÇÃO ACERCA DA REAL MOTIVAÇÃO A JUSTIFICAR A INEXISTÊNCIA DE MAIS ESTREITA CONVIVÊNCIA ENTRE A CRIANÇA E $O$ GENITOR NÃO GUARDIÃO}

Conforme o escólio de Corsi ${ }^{59}$, a negativa do filho de relacionar-se com um dos genitores adquire autêntica transcendência no momento em que se expressa num Tribunal, pois aí os mecanismos jurídicos e judiciais entram em funcionamento. É quando então o "não quero" passa a ser interpretado como infundado e absurdo. Simplesmente porque expressa um sentimento de rejeição e não se traduz numa fundamentada lista de razões que não são próprias do modo de funcionamento psicológico de crianças e adolescentes. Novamente, para a doutrina da "alienação parental", não se deve acreditar nas crianças, mas é lícito supor que há "algo por trás” de suas decisões.

No particular, isto é, quanto às naturais preferências demonstradas pelos filhos em relação aos pais (afinidades, gênero, personalidade), deve-se lembrar que há uma extensa variedade de explicações que precisam ser corretamente exploradas, incluindo a possibilidade muito real de que as crianças estejam a responder ao genitor não guardião com base em suas próprias experiências ${ }^{60}$.

59 No original: "La negativa de los/las hijos/as para relacionarse con uno de sus progenitores adquiere auténtica trascendencia en el momento en que se expresa en un juzgado y los mecanismos jurídicos y judiciales entram en funcionamento. Es entonces cuando el "no quiero" es interpretado como infundado o absurdo. Simplesmente porque expresa un sentimento de rechazo y no se traduce en una fundamentada lista de razones que no son proprias del modo de funcionamento psicólogico de niños/as y adolescentes. Nuevamente, para la doctrina de la "alienación parental" no hay que creerle a los/las niños/as, sino suponer que hay "algo detrás" de sus decisiones".CORSI, Jorge. El "síndrome de alienación parental", o el peligro que entrañan las teorias pseudocientíficas como base de las decisiones judiciales. Tradução livre e adaptada.

60 No original: "On the other hand, there are a variety of competing explanations that need to be explored-including the very real possibility that the children are responding to concerns based in their own experience with the parent from whom they feel estranged". National Council of Juvenile and Family Court Judges. (2006) Navigating Custody \& Visitation Evaluations in Cases with Domestic Violence: A Judge's Guide (2nd edition). Reno, NV: NCJFCJ. In DALLAM, Stephanie. Are "good enough" parents losing custody to abusive ex-partners? Tradução livre e adaptada. 
Ademais, não se pode perder de vista que a afirmação fundante da teoria de Gardner (de que as acusações maternas de abuso sexual praticado pelo genitor são, em sua maioria, falsas) não encontra amparo em nenhuma evidência científica. Pelo contrário, conforme demonstram Jones \& McGraw, falsas denúncias de abuso sexual ocorrem em não mais do que $2 \%$ dos $\operatorname{casos}^{61}$.

Não se pode desconsiderar, enfim, que outros fatores - que não a "alienação" promovida pelo genitor "alienante" - devam ser levados em conta na avaliação "mental" da criança, principalmente quando em meio ao divórcio dos pais, seja ele mais ou menos conturbado. O problema, parece, encontra-se equivocadamente colocado pelos gardneristas, que procuram tratar/ diagnosticar uma criança como se portadora de uma doença mental (a SAP) em virtude do comportamento de seus pais ${ }^{62}$.

61 No original: "Gardner's assertion that the vast majority of allegations of sexual abuse in divorce are false is not supported by the research. According to Jones \& McGraw (1987), false reports of sexual abuse occur in no more than $2 \%$ of cases. False reports in general, which include allegations fabricated by adults as well as false reports by children, are thought to total up to $8 \%$ of cases. This particular study is cited repeatedly in the literature because of is comprehensive nature and sound methodology (Corwin et al., 1987; Parkinson, 1990; Myers, 1989-90; Faller, 1998)". JENKINS, Suzanne. Are children protected in the family court? A perspective from western Australia, p. 7. Tradução livre e adaptada.

62 No original: "It is not appropriate to diagnose a child with a mental illness based on the parent's behaviour. In many cases known to the authors, both in practice an in supervision of other forensic evaluators, the child's behaviour could have been diagnosed as an adjustment disorder with anxiety or depression. Separation and divorce often means a new home or even two homes, new schools, new friends, and new schedules. Some may have symptoms associated with neurological immaturity or dysfunction. Some may have a severe case of PSTD from what they experienced as a trauma while others in the same home observing the same behaviour regarded the situation as inescapable. The factor called 'resilience', a hardiness that some children have and others do not, was not even listed as a consideration by the proposers of the PAD diagnosis" (p. 277) "Further, the danger of having a child receive a mental health diagnosis based on the behaviour of a parent during a high conflict or abusive custody battle is potentially more harmful than permitting the child to take a hiatus from parenting time with that parent and restoring contact at a later date, when hostilities have been reduced and fear and trauma triggers reduced. Finally, there are insufficient data to determine that rejection of a parent is harmful to the child or that the child and parent will remain disconnected over time if the child is permitted to reestablish a new safe and secure environment. What is being termed as alienation may well be a normal variant of family structure based on many variables in that particular family system and that forcing reunification may itself be more detrimental to the parent-child relationship over a period of time". Tradução livre e adaptada. 


\section{FALSAS ACUSAÇÕES DE ALIENAÇÃO PARENTAL}

Enquanto muito se fala acerca da alienação parental (AP) - terminologia, conceitos, diagnóstico e tratamentos -, pouco ou nada se menciona a respeito das falsas acusações de alienação parental e as terríveis consequências dessa prática.

Falsas alegações de alienação parental, de acordo com Turkat $^{63}$, podem ser definidas como a persistente e falsa (mendaz) afirmação feita por um dos genitores (o pai, via de regra), acusando o outro (a mãe, normalmente) de "jogar" os filhos "contra" aquele (o pai). Apresenta o autor importantes considerações a respeito da descrição clínica e motivos que normalmente embasam FAPAs (false allegations of parental alienation $)^{64}$. Primeiro, diz Turkat, falsas alegações de alienação parental (FAPAS) podem se dar de várias formas, mas o resultado final será sempre o mesmo, pois diz o pai, nuclearmente, que a mãe está "envenenando" as crianças, fazendo com que os filhos o rejeitem, através da imposição, por exemplo, de "falsas memórias". Desta forma, deve-se ter grande preocupação com o praticante de FAPAS, uma vez que não é normal afirmar a mãe, falsa e irresponsavelmente, que o pai cometeu abuso sexual contra seus filhos. A duas, ele anota que as motivações geradoras de FAPAs ainda estão para ser cientificamente estudadas, mas entende útil dividir as acusações em duas categorias: (1) a primeira, formada por aqueles que acreditam que tenha ocorrido alienação, independentemente do que faça o outro genitor (diz o autor que se trata de uma ilusão, um delírio) e (2) a segunda por aqueles que sabem ser a acusação infundada. Estes últimos, destaca, são maliciosos e buscam atingir, com a falsa acusação, alguns objetivos escusos tais como ofender o outro genitor, modificar as regras de visitas aos filhos, privar as crianças do convívio com o genitor falsamente acusado de provocar alienação, obter

63 No original: "an enduring erroneous claim by one parent that the other parent has engaged in behaviour designed to turn their mutual offspring against the parent making the charge". TURKAT, Ira Daniel. False Allegations of Parental Alienation, p.15. Tradução livre e adaptada.

64 TURKAT, Ira Daniel. False Allegations of Parental Alienation, p.16. Tradução livre e adaptada. 
vantagem no litígio (bens, pensão, visitação), escamotear seu próprio e inadequado comportamento e aumentar a sensação de controle sobre a vida da ex-mulher através dos filhos.

E, de fato, as consequências das FAPAs são enormemente negativas, pois implicam impor às crianças conflitos de lealdade, expondo-as a danos desnecessários e irreparáveis no relacionamento com os pais, obrigando-as a suportar separações dolorosas de um genitor amoroso, de quem efetivamente gostam, tudo baseado numa mentira maldosa. $\bigcirc$ genitor falsamente acusado pode não suportar a dor emocional imensurável, comprometendo com isso a qualidade do relacionamento com o filho afastado. Ademais, terá o acusado falsamente de provar sua inocência ${ }^{65}$.

65 No original:"False allegations of parental alienation (FAPAs) may emerge in a variety of shapes and forms, but the end result is the same. As enduring erroneous charge that the other parent is poisoning the children against the claimant. A person making a FAPA must be viewed with serious concern given that it is not normal to promulgate untrue assertions that someone has committed child abuse. The motivations generating FAPAs have yet to be studied scientifically but it would seem useful to divide the allegations into two pertinent categories: (1) those made by persons who fully believe the FAPA; and (2) those made by individuals who know the allegations are baseless. A parent who sincerely believes the other parent is turning their mutual offspring against them when it is clearly untrue, would appear to be suffering from a delusion. A delusion is a fixed belief that does not change in the face of contradictory data. This means that the individual interprets information in the environment idiosyncratically which fits the delusional content. In other words, it almost doesn't matter what the other parent actually says or does - the accuser has his or her interpretation and the delusional FAPA remains intact. A parent who makes a FAPA while knowing it to be counterfactual, is acting in a malicious manner. Such an individual makes the false allegations with a conscious determination to generate certain consequences. These may include trying to: 1 . Hurt the other parent; 2. Modify access; 3. Isolate the children; 4. Gain a litigation-based advantage; 5. Elicit other's support; 6. Provide cover for his/her own misbehavior; 7. Eliminate perceived threat from the other parent; 8. Elevate one's feeling of control and/or; 9. Obtain other benefits. The negative consequences for asserting a FAPA can be serious. Children may be ripped apart in loyalty conflicts, experience unnecessary damage to parental relationships, be forced to endure painful separations from a loving parent, and suffer behaviorally and emotionally. The parent falsely accused may not only bear immeasurable emotional pain and loss of relationship quality, he or she is placed on the defensive and may be forced to incur significant financial obligations in order to try to establish his or her innocence. Finally, the accuser also may face negative consequences, some of which may not have been anticipated". TURKAT, Ira Daniel. False Allegations of Parental Alienation, p.17. Tradução livre e adaptada. 
Não bastasse, revelam pesquisas sérias e recentes ${ }^{66}$ que, não raro, não é a genitora acusada a alienante, mas o contrário, isto é, o pai-abusador é quem busca sabotar a relação da mãe com as crianças. E situação como a descrita pode se constituir em verdadeira estratégia legal, isto é, quando a criança resiste às visitas, acusa-se a mãe de promover a alienação parental ${ }^{67}$, forçando-a a um acordo.

\section{A SAP NO BRASIL: A LEI E A JUSTIÇA}

Como já sinalizado no preâmbulo deste artigo, pouquíssimos países positivaram em lei ou densificaram em sua jurisprudência o uso da SAP, seja em face de sua nenhuma credibilidade científica, seja pelos graves reflexos que sua utilização acrítica e maliciosa pode gerar nas famílias e, principalmente, nas crianças.

Tanto é assim que os Tribunais da Inglaterra e País de Gales, por exemplo, a rejeitaram expressamente, enquanto o Departamento de Justiça do Canadá, após algum entusiasmo inicial e vacilação, finalmente desaconselhou seu uso. Sociedades médico-científicas e de saúde mental de todo o mundo ocidental civilizado, aí incluídas a OMS - Organização Mundial da Saúde, a APA - American Psychological Association, a Associação Americana de Psiquiatria e a combativa AEN Asociación Española de Neuropsiquiatria, a condenam energicamente.

O Brasil, porém, apressando-se para ingressar na contramão da história da ciência mundial e, assim, justificar seu renitente, orgulhoso e ufanista atraso, fez editar lei sobre algo que não existe (a tal síndrome); desde então a SAP passa a ser

66 No original: "This issue has critical importance when reviewing Johnston, Olesen et al. (2005a, 2005b) and Johnston, Lee et al. (2005) research finding that the alienator in many of the cases they studied was not the mother, as was the court finding, but rather the father, who was an abuser alienator and who attempted to or actually sabotaged the mother's relationship with the children" (p. 270). Tradução livre e adaptada.

67 SOUSA, Maria Inês Costa. Regulação das responsabilidades parentais e resistência às visitas: Caracterização de processos de avaliação periciais, p. 9. 
verdade incontrastável, mostrando-se necessário, para afastar qualquer possibilidade de malferimento ao mainstream, enxovalhar e desqualificar os que a questionam por ausência de cientificidade e seriedade mínimas.

A lei brasileira não utiliza o termo SAP em seu texto, dando com isso, eufemicamente, a impressão de neutralidade científica (pois as associações de psiquiatria e psicologia do mundo todo negam, pela ausência de evidência e sindicância, tratar-se de uma "síndrome").

$\mathrm{Na}$ justificação ao projeto de le $^{68}$ resta evidenciada a não distinção legal entre AP e SAP, incorporando visão deformada acerca da "tirania" do guardião (ou quis dizer guardiã?), revelando a bibliografia ali invocada (em todos os textos utiliza-se a expressão "síndrome" (sic)) inescondível desacerto científico. Mostram também as fontes informais indicadas fragoroso preconceito de gênero, bastando observar as sugestões individuais que auxiliaram na formatação da lei: Associações "Pais para Sempre”, "Pai Legal”, "Pais por Justiça”, entre outras.

A lei que trata da AP (Lei n. 12.318/2010) no país segue à risca a cartilha gardneriana, aplicando com maestria a "teoria da ameaça" (alteração da guarda do filho, proibição de contato com o genitor alienante (?), obrigação de convívio com o genitor não guardião/alienado (?) mesmo contra a vontade da criança, a fim de a "reprogramar"), mas não deixou escapar a oportunidade de aprimorar a perversidade infligida contra as mulheres e filhos, praticando evidente discriminação de gênero, quando

68 "Cabe sublinhar que a presente justificação é elaborada com base em artigo de Rosana Barbosa Ciprião Simão, publicado no livro "Síndrome da Alienação Parental e a Tirania do Guardião - Aspectos Psicológicos, Sociais e Jurídicos" (Editora Equilíbrio, 2007), em informações do site da associação "SOS Papai e Mamãe" e no artigo "Síndrome de Alienação Parental", de François Podevyn, traduzido pela "Associação de Pais e Mães Separados' - APASE, com a colaboração da associação "Pais para Sempre". Também colaboraram com sugestões individuais membros das associações "Pais para Sempre", "Pai Legal", "Pais por Justiça" e da sociedade civil. (...) Para concluir, permito-me reproduzir, por sua importância e riqueza, artigo publicado no ano de 2006 pela Desembargadora Maria Berenice Dias, do Tribunal de Justiça do Rio Grande do Sul, intitulado "Síndrome da alienação parental, o que é Isso?" In http://www. camara.gov.br/sileg/integras/601514.pdf. Consultado em 4/9/2014. 
trata, inquestionavelmente, de "alienação marental", permitindo levianamente que indícios (?) - artigos 4o e 5º - embasem temerosíssimas decisões judiciais já em sede cautelar, como vem decidindo o eg. STJ ao aplicar ao genitor "alienante" (?) (diga-se claramente, à mulher) um extenso rol de "punições”, que vão da advertência à suspensão da autoridade parental, passando pela ampliação do regime de convivência familiar em favor do genitor alienado(?), pela estipulação de multa, acompanhamento psicológico, alteração da guarda e fixação cautelar (!) do domicílio da criança.

É evidente o caráter francamente intimidador do preceito, servindo à barganha denunciada pela boa ciência, como aqui ilustrado fartamente e, mais, nos casos-limite, à proteção de genitores que abusam sexualmente dos filhos, um dos pontos cardeais da "teoria" gardneriana, já se viu.

A normativa brasileira, irrefragavelmente, escancarou as portas à selvajaria, ao backlash, aquele contramovimento social que busca legitimar manifestações de violência contra as mulheres e crianças ${ }^{69}$, ao permitir a desqualificação sumária do discurso das vítimas (mãe e filhos) em decorrência do facilismo promovido pelos "indícios" legais. Como referido pela literatura científica indicada, qualquer reação protetivo-materna contra os abusos (sexuais ou morais) praticados pelo pai dá corpo ao contra-argumento paterno de alienação parental urdida pela ex-mulher, marca indelével e estigmatizante que a acompanhará para sempre e, assim, desacreditará qualquer denúncia por ela apresentada contra o agressor.

O texto legal institui também o adultismo ao considerar apenas os desejos e a carência afetiva do genitor, sem se preocupar com os sinceros sentimentos externados pelos filhos em meio aos conflitos vivenciados pelos pais, tratando as crianças como "entidades passivas", suscetíveis de toda ordem de mani-

69 VARGAS, Andrés Castillo. BADILLA, Ivannia Chinchilla. Backlash y abuso sexual infantil: la emergencia de nuevas amenazas a la protección de los derechos humanos de las personas menores de edad. Revista Latinoamericana de Derechos Humanos, v. 22, enero-junio 2011, p. 105-25. 
pulação materna, como se não possuíssem sua própria percepção da realidade.

Os Juízes brasileiros de primeira instância, notadamente, em que pese a sabida e lamentável ausência de estrutura física e humana qualificada a auxiliá-los, têm demonstrado prudência e cautela na aplicação da nova lei, até porque são eles os que vivenciam nos fóruns os dramas reais (e não ficcionais, documentais) envolvendo famílias em conflito. E é seu papel refletir (e decidir) cuidadosamente quando em discussão a guarda dos filhos do casal, principalmente em face de "teorias avançadas" desprovidas de qualquer aporte científico, como a SAP. A prova pericial (laudos psicológicos, psiquiátricos, estudos sociais etc.) apresenta-se frequentemente útil aos Juízes, mas estes devem "fazer o dever de casa", não se demitindo da responsabilidade que lhes toca primariamente, confiando acriticamente na visão do expert, uma vez que em áreas como psicologia e psiquiatria, por exemplo, existe (e é aceita) uma ampla gama de pontos de vista, técnicas de abordagem, entendimento dos problemas e terapêuticas. Por isso se diz que aos Juízes cabe fazer as "perguntas difíceis", e que tal habilidade deve ser empregada na resolução dos conflitos familiares ${ }^{70}$.

Uma visita ao sítio do eg. STJ ${ }^{71}$ revela possuir ele apenas três acórdãos envolvendo a expressão "alienação parental" (AP), mas em nenhum deles é enfrentada a matéria de fundo, que se limita a decidir dois temas: o recurso cabível para o Tribunal e conflitos de competência (um em embargos de declaração).

70 No original: "Lawyers, judges, and mental health professionals who deal with child custody issues should think carefully and respond judiciously when claims based on either theory are advanced." (...) "Although the use of expert testimony is often useful, decision-makers need to their homework rather than rely uncritically on experts' views. This is particularly true in fields such as psychology and psychiatry, where even experts have a wide range of differing views, and professionals, whether by accident or design, sometimes offer opinions beyond their expertise. Lawyers and judges are trained to ask hard questions, and that skill should be employed here". BRUCH, Carol S. Bruch, Parental Alienation Syndrome and Alienated Children - getting it wrong in child custody cases, p. 399. Tradução livre e adaptada.

71 Consulta realizada em 2/9/2014. 
Todavia, em sede de decisões monocráticas, encontramos 58 ocorrências envolvendo AP e cinco episódios em que foi utilizada a expressão SAP. Em termos cronológicos, a primeira decisão em que citada a AP data de 2009, antes pois da edição da lei brasileira n. 12.318/2010. O ano de 2014 (até o final do mês de agosto) sugere um aumento exponencial de casos em que se discute a AP, havendo 28 registros do termo.

Uma análise qualitativa de tais decisões monocráticas parece indicar que os temores externados pelos incontáveis e destacados opositores da SAP gardneriana estão a se confirmar insofismavelmente, inclusive pela aplicação da "teoria da ameaça”. Assim, por exemplo, em 11 decisões monocráticas é levantada a AP como matéria de defesa criminal (abusadores de crianças alegam terem sido implantadas "falsas memórias" - crimes praticados contra a dignidade sexual, especialmente em face de vulnerável - pelas mães com o exclusivo intuito de prejudicá-los). A quase totalidade das decisões corrobora a discriminação de gênero praticada contra a mulher, inclusive com o deferimento de ampliação das visitas ao genitor em medida cautelar, sem qualquer estudo ou laudo técnico a embasá-la, bastando para justificar tão drástica mudança a alegação do pai e os "indícios" mencionados na lei. Em alguns casos houve a suspensão do poder familiar da mãe e entrega da guarda da criança ao genitor, com proibição de visitação materna por 30 dias. Noutros, restou a mãe advertida quanto à "possível" (sic) instalação da SAP. Por vezes, demite-se o STJ de analisar o tema invocando a ementa $\mathrm{n}$. 7 de sua súmula (vedação do reexame de prova), o que parece acertado. Noutras hipóteses, porém, mergulha o mesmo julgador na prova produzida sem ter tido qualquer contato com as partes, especialmente com as crianças que serão fortemente atingidas pela decisão, fazendo pouco caso do princípio da "confiança no juiz da causa". Em vários casos a matéria subjacente à discussão da $\mathrm{AP}$ é a fixação do valor da pensão alimentícia aos filhos, o que se mostra em consonância com as denúncias apresentadas pelas associações 
médico-psiquiátricas mais gabaritadas. $\mathrm{O}$ adultismo também se mostra presente nas decisões, pois embora seja citado "o melhor interesse" da criança, em raras oportunidades foi o seu sincero desejo levado em consideração.

\section{CONCLUSÃO}

1. Separações e divórcios, independentemente de serem mais ou menos conflitivos, por vezes envolvem sentimentos contraditórios como ressentimento, raiva, mágoa, aflição, pena, medo, alívio e outros.

2. Em muitos desses conflitos, são os filhos voluntária ou involuntariamente envolvidos pelos pais, seres humanos então fragilizados, em face da ruptura do tecido familiar.

3. As consequências daí derivadas não podem ser reduzidas a modelos simplistas, baseados em pseudociência que se presta, em muitas oportunidades, para acobertar sentimentos pouco nobres e até abusos sexuais cometidos contra as crianças.

4. Tanto a AP (alienação parental) como especialmente a SAP (síndrome da alienação parental) não gozam de qualquer prestígio nos tribunais e sociedades médicas e de profissionais da psicologia em países de larga tradição, como Estados Unidos, Inglaterra, Espanha e Portugal, por exemplo, justamente pela escassez de evidências científicas a sustentar suas conclusões pouco convincentes, sendo por isso tachadas de pseudocientíficas. Profissionais renomados de incontáveis países vinculados à área da saúde mental (médicos, pesquisadores, psiquiatras, psicólogos) e organizações internacionais como a OMS - Organização Mundial da Saúde, a APA - American Psychological Association, a Associação Americana de Psiquiatria e a combativa AEN - Asociación Española de Neuropsiquiatria condenam sua existência, refutando veementemente a AP como síndrome. 
5. Ao contrário do afirmado pelos gardneristas, inexistem estudos científicos que comprovem ou mesmo sugiram que a imposição de convívio com o pai rejeitado melhore a saúde mental da criança.

6. Destacam os opositores das "teorias" de Gardner que a SAP configura, em particular, uma invenção acientífica criada para permitir aos pais barganhar bens, visitas e pensionamento alimentício com as mães, tornando-as reféns dos seus desejos e mascarando, em casos-limite, crimes de abuso sexual infantil levados a efeito pelos próprios genitores; demonstram estudos científicos qualificados serem raríssimas as falsas denúncias de abuso sexual (não mais de $2 \%$ dos casos).

7. A aplicação das "teorias" gardnerianas da AP e da SAP baseadas na "terapia da ameaça" escancaram evidente preconceito de gênero contra as mulheres, sendo mais honesto e transparente falar em "alienação marental", e não "parental". Além disso, as acusações de alienação parental encontram-se vinculadas pela literatura ao adultismo e ao suprimento unilateral das carências afetivas do pai, sem levar em consideração os desejos sinceros que as crianças e adolescentes já possuem em relação à visitação e convivência com os genitores. Afirma-se também que tais "teorias" fazem parte de autêntico backlash, conhecido movimento reacionário patrocinado por setores mumificados da igreja e da política incomodados com as conquistas emancipatórias das mulheres e minorias marginalizadas.

8. A perversidade da SAP está na impossibilidade de sua negação. Qualquer comportamento protetivo da mãe em relação aos filhos é interpretado como sinal de instabilidade, e eventual resistência materna aos arroubos paternos (como horários de visita intempestivos) constitui prova irrefutável da alienação por ela patrocinada e da "programação" (contra o pai) a que subme- 
tida a criança. Qualquer movimento de contrariedade por si só confirma o diagnóstico.

9. Há de se considerar dois grupos de falsos acusadores de alienação parental: os delirantes, que acreditam estar mesmo sendo alienados, e os maliciosos, que se utilizam do argumento, sabendo-o falso, apenas para obter vantagem no litígio.

10. No Brasil, tanto a AP como a SAP encontraram terreno fértil à propagação rápida e fácil, sendo editada (e aplicada) lei sobre algo que não existe (a tal síndrome). Encampou a lei brasileira os ensinamentos estampados na cartilha gardneriana (teoria da ameaça, alteração de guarda, obrigação de convívio da criança com genitor não guardião, "reprogramação" etc.), com requintes de perversidade próprios de um país intelectualmente miserável e moralmente desintegrado; contentou-se, para tanto, com "indícios" de alienação parental, abrindo aí espaço para extenso rol punitivo, da advertência (passando pela multa) até chegar à suspensão da autoridade parental.

11. A lei brasileira não só não esconde como se jacta de seu caráter intimidador, servindo à larga às barganhas e negociatas de pensão, bens e visitação, sem contar a fragilização das mães no que se refere à proteção dos filhos vítimas de abuso sexual pelos pais. Preconceito de gênero, adultismo, estímulo à vulnerabilidade materna e backlash encontram-se vistosamente estampados na normativa.

12. A Justiça brasileira de primeira instância, mesmo não contando com nenhuma ou quase nenhuma estrutura física e humana de apoio qualificado, tem-se demonstrado conscientemente prudente e cautelosa na aplicação da lei da AP, certamente porque são eles, os Juízes, os que vivenciam nos fóruns os dramas reais (e não ficcionais) das famílias brasileiras. 
13. Análises quantitativas e qualitativas das decisões do eg. STJ sobre AP revelam a maneira acrítica com que a jurisprudência superior tem decidido as questões ali postas, servindo a AP e a SAP, inclusive, como matéria de defesa criminal em casos envolvendo prática de atos contra a dignidade sexual, nomeadamente em face de vulnerável. Também restou constatada discriminação de gênero em provimentos cautelares decididos sem nenhum estudo ou laudo técnico a suportá-los, modificando-se visitas e guarda em favor dos pais, tudo sob o insípido argumento "indiciário". Mães receberam a pena judicial de advertência por "possivel (sic) instalação da SAP", quando se sabe que a "síndrome" não é aceita em nenhuma parte do mundo. Em vários julgados a matéria real, subjacente à epidérmica discussão da $\mathrm{AP}$ ou da $\mathrm{SAP}$, dizia respeito à pensão alimentícia ou às facilidades de visitação desejadas pelo pai.

Abstract: The terms "parental alienation" (PA) and "parental alienation syndrome" (PAS) have become part of the national legal vocabulary being used by Courts throughout the country only recently, in cases involving troubled divorces. The matter was positively valued in Brazil exactly four years ago from the enactment of Law n. 12.318, August 2010, having received almost unanimous applause, which seemed to occur in a ludicrously uncritical way, considering no other country has enacted a law on the subject and the Courts and societies of psychiatry of the traditional Western Countries consistently reject it. The already vast national literature on the subject, in its absolute majority, shows itself very favorable to law enforcement and to the position of the creator of the term PAS, the American Richard Gardner. The new law, says a silent minority, having been approved by a markedly masculine Parliament, expresses strong prejudice gender, shows antinomy and is full of vague concepts and penalties (to be applied 
logically, in the vast majority of cases, to women) at least reckless since these penalties have as final recipients, perversely, not the ex-wife, but precisely the children who all say they want to preserve. In Brazil, unlike that which has long taken place in Europe and the United States, denser and responsible scholarly discussion about the PA and PAS is nonexistent; this weakness is then reflected in judicial decisions.

Keywords: Parental alienation. Syndrome. Gender prejudice. Maternal vulnerability. Backlash.

\section{REFERÊNCIAS}

ASOCIACIÓN ESPAÑOLA DE NEUROPSIQUIATRIA. La Asociación Española de Neuropsiquiatria hace la siguiente declaración en contra del uso clinico y legal del llamado síndrome de alienación parental. In Revista de la Asociación Española de Neuropsiquiatria, vol.30, n. 107, septiembre, 2010, p. 535-49, Asociación Española de Neuropsiquiatria, España. Disponível em: www. googleacademico.com. Acesso em: 19/8/2014.

BERNET, William; BAKER, Amy J.L.. Parental Alienation, DSM-5 and ICD-11: Response to Critics. In Journal of the American Academy of Psychiatry and the Law Online. jaapl March 1, 2013, vol. 41, n. 1, 98-104. Disponível em: www.googleacademico.com. Acesso em: 15/8/2014.

BRUCH, Carol S.. Parental Alienation Syndrome and Alienated Children getting it wrong in child custody cases, p. 381, Child and Family Law Quaterly, p. 527-52, 2001.

BULFINCH, Thomas. O livro de ouro da mitologia: histórias de deuses e heróis. Tradução de David Jardim Júnior. 8 ed. rev. e ilustrada. Rio de Janeiro: Ediouro, 1999, p.164.

CAHALI, Yussef Said. Divórcio e Separação. 10a ed. São Paulo: Revista dos Tribunais, 2002, p. 930-1.

CANCROFT, L.R. (1998). Understanding the batterer in custody and visitation disputes. In DALLAM, Stephanie. 
CORSI, Jorge. El "síndrome de alienación parental", o el peligro que entrañan las teorias pseudocientíficas como base de las decisiones judiciales. In Themis: revista jurídica de igualdad de género, n. 1, p. 73-7, 2007. Disponível em: www. googleacademico.com. Acesso em 11/8/2014.

DALLAM, S. J. Are "good enough" parents losing custody to abusive ex-partners?. 2008. Disponível em: www.googleacademico.com. Acesso em: 16/8/2014.

JACK, Jennifer. Child Custody and Domestic Violence Allegations: New York's Approach to Custody Proceeding Involving Intimate Partner Abuse. Alb. Gov't L. Rev., v. 5, p. 885, 2012.

JENKINS, Suzanne. Are children protected in the family court? A perspective from western Australia. Paper presented at the Child Sexual Abuse: Justice Response or Alternative Resolution Conference convened by the Australian Institute of Criminology and held in Adelaide, 1-2 May, 2003. 14 p.

KEATING, G. (February 11, 2001). Group seeks reform for family court Bias against women alleged. San Gabriel Valley News (Pasadena, CA) in DALLAM, Stephanie.

KLEINMAN, T.G. Child Protection and Child Custody: Domestic Violence, Abuse, and Other Issues of Child Protection. Journal of Child Custody, 1 (1), 115-26, 2004.

Law Society of British Columbia Gender Bias Committee (1992). Gender equality in the justice system, Volume II. Author. (as cited in: Penfold, S.P. (1997). Questionable beliefs about child sexual abuse allegations during custody disputes. Canadian Journal of Family Law, 14, 11-30) in DALLAM, Stephanie, Are "good enough" parents losing custody to abusive ex-partners?

National Council of Juvenile and Family Court Judges. (2006) Navigating Custody \& Visitation Evaluations in Cases with Domestic Violence: A Judge's Guide (2nd edition). Reno, NV: NCJFCJ. In DALLAM, Stephanie. Are "good enough" parents losing custody to abusive ex-partners?

RAND, Deirdre C.. Parental Alienation Critics and the Politics of Science. In. The American Journal of Family Therapy (online), 49:48-71, 2011. Disponível em: www.googleacademico.com. Acesso em 15/8/2014.

Revista de la Asociación Española de Neuropsiquiatria, p. 535-7. 
ROCKEY, Arlaine. (2003). Custody Cases: Protecting Children from Sexual Abuse. in DALLAM, Stephanie. Are "good enough" parents losing custody to abusive ex-partners?

Dicionário eletrônico Michaelis, http://michaelis.uol.com.br/.

SOUSA,, Maria Inês Costa. Regulação das responsabilidades parentais e resistência ás visitas: Caracterização de processos de avaliação periciais, p. 9.

STAHL, Philip M. Understanding and Evaluating Alienation in High-Conflict Custody Cases, 2010. Disponível em : www.googleacademico.com. Acesso em $1 \% / 8 / 2014$.

STAHLY G.B; KRAJEWSKI L.; Loya, B.; GERMAN G.; FARRIS W.; HILSON, N.; VALENTINE, J. (2004). Protective Mothers in Child Custody Disputes: A Study of Judicial Abuse. In Disorder in the Courts: Mothers and Their Allies Take on the Family Law System (a collection of essays) in DALLAM, Stephanie, Are "good enough" parents losing custody to abusive ex-partners?

The Voices of Women Organizing Project (VOW) 2008 Justice Denied: How Family Courts in NYC Endanger Battered Women and Children. Brooklyn, NY: Battered Women's Resource Center in DALLAM, Stephanie, Are "good enough" parents losing custody to abusive ex-partners?

TURKAT, Ira Daniel. False Allegations of Parental Alienation. American Journal of Family Law, 2005. Disponível em: www.googleacademico.com. Acesso em 18/8/2014.

VARGAS, Andrés Castillo; BADILLA, Ivannia Chinchilla. Bachlash y Abuso Sexual Infantil: la emergencia de nuevas amenazas a la protección de los derechos humanos de las personas menores de edad. Revista Latinoamericana de Derechos Humanos, v. 22, n. 1, p. 105-126, 2011. Disponível em: www. googleacademico.com Acesso em 29/8/2014.

WALKER, L.E.; BRANTLEY, K.L.; RIGSBEE, J.A.; (2005). A Critical Analysis of Parental Alienation Syndrome an its Admissibility in the Family Court. Journal of Child Custody, 1(2), 47-74 in DALLAM, Stephanie. Are "good enough" parents losing custody to abusive ex-partners?

WALKER, Lenore E.; SHAPIRO, David L. Parental alienation disorder: why label children with a mental diagnosis? Journal of Child Custody, v. 7, n. 4, 
p. 266-286, 2010. Disponível em: www.googleacademico.com Acesso em 29/8/2014.

WIKIPEDIA, a enciclopédia livre. Disponivel em: http://pt.wikipedia. org/wiki/ Wikip\%C3\%A9dia:P\%C3\%A1gina_principal. Acesso em $11 / 8 / 2014$. 